\title{
Forest mosses sensitively indicate nitrogen deposition in boreal background areas
}

\section{Salemaa, Maija}

2020-06

Salemaa , M , Kieloaho , A-J , Lindroos , A-J , Merilä , P , Poikolainen , J \& Manninen , S 2020 , ' Forest mosses sensitively indicate nitrogen deposition in boreal background areas ' , Environmental Pollution , vol. 261 , 114054 . https://doi.org/10.1016/j.envpol.2020.114054

http://hdl.handle.net/10138/339798

https://doi.org/10.1016/j.envpol.2020.114054

cc_by_nc_nd

acceptedVersion

Downloaded from Helda, University of Helsinki institutional repository.

This is an electronic reprint of the original article.

This reprint may differ from the original in pagination and typographic detail.

Please cite the original version. 


\section{Forest mosses sensitively indicate nitrogen deposition in boreal background areas}

2 Maija Salemaa $^{\mathrm{a}^{*}}$, Antti-Jussi Kieloaho ${ }^{\mathrm{a}}$, Antti-Jussi Lindroos ${ }^{\mathrm{a}}$, Päivi Merilä ${ }^{\mathrm{b}}$, Jarmo

3 Poikolainen $^{\mathrm{b}}$, Sirkku Manninen $^{\mathrm{c}}$

$4 \quad{ }^{a}$ Natural Resources Institute Finland (Luke), Latokartanonkaari 9, FI-00790 Helsinki,

$5 \quad$ Finland

6 b Natural Resources Institute Finland (Luke), P.O. Box 413, FI-90570 Oulu, Finland

$7 \quad{ }^{c}$ Ecosystems and Environment Research Programme, Faculty of Biological and

8 Environmental Sciences, University of Helsinki, P.O. Box 65 (Viikinkaari 1), 00014

9 Helsinki, Finland

10

$11 *$ Corresponding author, maija.salemaa@luke.fi

12 


\section{Abstract}

15 Mosses take up nitrogen $(\mathrm{N})$ mainly from precipitation through their surfaces, which makes

16 them competent bioindicators of $\mathrm{N}$ deposition. We found positive relationships between the

17 total $\mathrm{N}$ concentration (mossN\%) of common terrestrial moss species (feather mosses

18 Pleurozium schreberi and Hylocomium splendens, and a group of Dicranum species) and 19 different forms of $\mathrm{N}$ deposition in 11-16 coniferous forests with low $\mathrm{N}$ deposition load in

20 Finland. The mosses were collected either inside (Dicranum group) or both inside and outside

21 (feather mosses) the forests. Deposition was monitored in situ as bulk deposition (BD) and 22 stand throughfall (TF) and detected for ammonium $\left(\mathrm{NH}_{4}{ }^{+}-\mathrm{N}\right)$, nitrate $\left(\mathrm{NO}_{3}{ }^{-} \mathrm{N}\right)$, dissolved 23 organic $\mathrm{N}(\mathrm{DON})$, and total $\mathrm{N}\left(\mathrm{N}_{\mathrm{tot}}, \mathrm{kg} \mathrm{ha}^{-1} \mathrm{yr}^{-1}\right)$. $\mathrm{N}_{\text {tot }}$ deposition was lower in TF than BD 24 indicating that tree canopies absorbed $\mathrm{N}$ from deposition in $\mathrm{N}$ limited boreal stands.

25 However, mossN\% was higher inside than outside the forests. In regression equations, 26 inorganic $\mathrm{N}$ in $\mathrm{BD}$ predicted best the mossN\% in openings, while DON in TF explained most 27 variation of moss $\mathrm{N} \%$ in forests. An asymptotic form of mossN\% vs. TF $\mathrm{N}_{\text {tot }}$ curves in forests 28 and free $\mathrm{NH}_{4}{ }^{+}-\mathrm{N}$ accumulation in tissues in the southern plots suggested mosses were near the $\mathrm{N}$ saturation state already at the $\mathrm{N}_{\text {tot }}$ deposition level of $3-5 \mathrm{~kg} \mathrm{ha}^{-1} \mathrm{yr}^{-1}$. N leachate from ground litterfall apparently also contributed the N supply of mosses. Our study yielded new information on the sensitivity of boreal mosses to low $\mathrm{N}$ deposition and their response to different $\mathrm{N}$ forms in canopy TF entering moss layer. The equations predicting the $\mathrm{N}_{\text {tot }}$ deposition with mossN\% showed a good fit both in forest sites and openings, especially in case of $P$. schreberi. However, the open site mossN\% is a preferable predictor of $\mathrm{N}$ deposition in monitoring studies to minimize the effect of tree canopies and $\mathrm{N}$ leachate from litterfall on the estimates. 
Keywords: Bryophytes, boreal forest, critical load, dissolved organic nitrogen, canopy effect Capsule: Mosses take up different $\mathrm{N}$ forms from precipitation depending on their supply

\section{Introduction}

The anthropogenic nitrogen $(\mathrm{N})$ emissions originating from agriculture, animal husbandry and the use of fossil fuels (vehicles, energy production, industry) are dry and wet deposited onto terrestrial ecosystems as oxidized and reduced forms of N (Erisman et al. 2007, Mayer et al. 2015). Excess of $\mathrm{N}$ deposition has considered responsible to eutrophication of vegetation and nutrient unbalances in many habitats worldwide (Dirnböck et al. 2018). The effects of atmospheric $\mathrm{N}$ deposition on vegetation depend on the cumulative amount of $\mathrm{N}$ deposited in the past (Bernhardt-Römermann et al. 2015) and on the forms and amounts of current $\mathrm{N}$ deposition. In addition, the effects depend on habitat type and vary among the plant species and guilds (Perring et al. 2018). In this regard, poikilohydric mosses (bryophytes) form a distinctive group among major plant guilds of the understorey vegetation in boreal forests. Mosses lack cuticle layer and many species have large cationic exchange capacities which enable them to take up nutrients through the entire surface (Glime 2007). These properties make mosses one of the most sensitive plant groups to $\mathrm{N}$ deposition but also suitable organisms to be used as bioindicators (Pitcairn et al. 2006).

Terrestrial mosses take up most of nitrogen $(\mathrm{N})$ they need from atmospheric wet and dry deposition (Forsum et al. 2006, Hawkins et al. 2018) although some of the $\mathrm{N}$ in mosses originates from the soil (Ayres et al. 2006, Liu et al. 2013). Moreover, biological fixation of atmospheric $\mathrm{N}_{2}$ by moss-associated cyanobacteria contributes to moss $\mathrm{N}$ content especially in nutrient-limited northern ecosystems with a low $\mathrm{N}$ deposition $\left(<3-5 \mathrm{~kg} \mathrm{ha}^{-1} \mathrm{yr}^{-1}\right)$ (Rousk et al. 2013, Salemaa et al. 2019). In some experimental exposures, boreal mosses have been 
shown to prefer ammonium $\left(\mathrm{NH}_{4}{ }^{+}\right)$and dissolved organic $\mathrm{N}(\mathrm{DON})$ over nitrate $\left(\mathrm{NO}_{3}{ }^{-}\right)$as $\mathrm{N}$ source (Forsum et al. 2006, Nordin et al. 2006). However, mosses have an ability to also take up $\mathrm{NO}_{3}{ }^{-}$from spraying solution (Solga and Frahm 2006, Hawkins et al. 2018, van den Elzen et al. 2018), but $\mathrm{NO}_{3}{ }^{-}$assimilation of mosses may be suppressed by the high supply of $\mathrm{NH}_{4}{ }^{+}$ and DON (Liu et al. 2013). The contribution of DON (especially the amino acid component) to moss $\mathrm{N}$ supply is suggested to be important in $\mathrm{N}$ limited northern ecosystems (Forsum et al. 2006) and when $\mathrm{NH}_{4}{ }^{+}$deposition is low (Liu et al. 2013). Interestingly, DON has been found to serve as an important source of $\mathrm{N}$ also in sub-tropical epiphytic mosses growing in nutrient-poor canopy habitat in cloud forests (Song et al. 2016).

Tree layer controls the amount and forms of atmospheric $\mathrm{N}$ deposition entering the moss layer of boreal forests, and more knowledge on the response of terrestrial mosses to different $\mathrm{N}$ forms in TF precipitation is needed. Tall tree canopies filter more efficiently atmospheric gases (e.g. $\mathrm{NO}_{2}, \mathrm{NH}_{3}$, and $\mathrm{HNO}_{3}$ ) and aerosols (e.g. $\mathrm{NO}_{3}{ }^{-}, \mathrm{NH}_{4}{ }^{+}$) than lower vegetation in open areas due to aerodynamically rough surfaces of trees (Fowler et al. 1999, Neirynck et al. 2007). The dry-deposited gaseous and particulate $\mathrm{N}$ compounds are absorbed and retained in the canopy (Fowler et al. 2009), where they are dissolved in water and converted from one form to another. In addition to gaseous $\mathrm{N}$ compounds, water-dissolved $\mathrm{NH}_{4}{ }^{+}$and $\mathrm{NO}_{3}{ }^{-}$may be taken up by tree foliage in $\mathrm{N}$-limited forests decreasing $\mathrm{N}$ deposition to the forest floor. In high-deposition sites, $\mathrm{NH}_{4}{ }^{+}$and $\mathrm{NO}_{3}{ }^{-}$are in turn leached from the foliage (de Schrijver et al. 2007, Neirynck et al. 2007), while DON is released in unpolluted or less polluted forests (Mustajärvi et al. 2008, Izquieta-Rojano et al. 2016).

Mosses are widely used as a bioindicator for long-term trends and regional distribution of total N ( $\mathrm{N}_{\text {tot }}$ ) deposition in Europe (Harmens et al. 2011, 2014; Skudnik et al. 2014, Meyer et al. 2015, Kosonen et al. 2018). The lowest total $N$ concentrations $(<0.6 \%)$ of mosses 
87 (mossN\%) are measured in background areas in northern Europe (Poikolainen et al. 2009) and Scotland with annual $\mathrm{N}_{\text {tot }}$ deposition $<3 \mathrm{~kg} \mathrm{ha}^{-1} \mathrm{yr}^{-1}$ (Harmens et al. 2011), whereas the highest mossN\% (> 2.5\%) are measured in areas of intensive agriculture with high $\mathrm{NH}_{3}$ emissions e.g. in the UK (Pitcairn et al. 2006) and Germany (Harmens et al. 2014, Meyer et al. 2015). In remote boreal areas, a possibility to apply mossN\% as bioindicator of $\mathrm{N}$ deposition instead of costly maintenance of continuous monitoring systems is of special interest. However, sufficient knowledge is still lacking on how forest structure and tree species composition affect the relationship between atmospheric $\mathrm{N}$ deposition and moss $\mathrm{N} \%$ in field conditions e.g. to enable preparation of appropriate sampling protocols for the purpose.

In this study we investigated and modelled the relationships between the mossN\% and the background $\mathrm{N}$ deposition in boreal forests of Finland with a low $\mathrm{N}$ deposition in the European scale. We compared the relationship between mossN\% and $\mathrm{N}$ deposition both in forest openings (bulk deposition, BD) and inside forests (TF) including different $\mathrm{N}$ fractions in deposition $\left(\mathrm{N}_{\text {tot }}, \mathrm{NH}_{4}{ }^{+}-\mathrm{N}, \mathrm{NO}_{3}{ }^{-}-\mathrm{N}\right.$ and DON). We hypothesised that mossN\% is equal or higher in the forest than in open sites (Kluge et al. 2013, Skudnik et al. 2014, Meyer et al. 2015) due to 1) canopy drip of DON (Harmens et al. 2014) and 2) N leachate from litterfall shed on the forest floor. In other words, we suggest that DON significantly contributes to mossN\% (Kielland 1997, Forsum et al. 2006, Liu et al. 2013) in northern forests with low N deposition, given that the assimilation cost of organic $\mathrm{N}$ (amino acids) is expected to be lower than that of inorganic $\mathrm{N}$, especially $\mathrm{NO}_{3}{ }^{-}$(Chapin et al. 1993). Furthermore, $\mathrm{N}$ leaching by precipitation from litterfall (senescent needles and other canopy material; Ukonmaanaho and Starr 2001) may give additional input of $\mathrm{N}$ to mosses, and we predict a positive relationship between the moss $\mathrm{N} \%$ and the amount of $\mathrm{N}$ leachate at a regional scale. 


\section{2. Materials and methods}

\subsection{Study sites}

Moss samples and precipitation (water and snow) were collected from intensively monitored coniferous plots in Finland (UN-ECE ICP Forests Level II network, Merilä et al. 2014) in three different inventories carried out in (1) 16 forest plots in 2009, (2) 11 forest openings in 2009-2010, and (3) in 10 forest plots in 2002-2003 (a subset of the plot network studied in 2009) (Table 1). The study sites were located along the climatic gradient between the northern latitudes $60-70^{\circ}$. The plots were divided into two groups, hereafter referred as "south" and "north" according to their situation in the boreal vegetation subzones of Finland (Fig. 1, Table 2). The first group consisted of the plots in the southern boreal and the second one those in the middle and northern boreal subzones. In the "north" the $\mathrm{N}$ deposition level is lower (Fig. 2), growing season shorter, the soil less-fertile and basal area of forests lower than in the "south" (Hilli et al. 2008). The forest data in 2009 consisted of seven Scots pine and nine Norway spruce dominated plots. Majority of the plots (12) were under conventional forest management and four (plot nos. 3, 19, 20, 21) were located in protected areas. We refer to the plots using their ICP Forests codes (Merilä et al. 2014). Basic characteristics of tree stand, understorey vegetation and soil are given in Table 2. All plots were located in background areas without any substantial nearby $\mathrm{N}$ emission sources, except the spruce plot Uus23S in the western coast. We excluded this plot from statistical analyses because it was an outlier due to $\mathrm{N}$ emissions from a fox fur farm in vicinity, but tested its effect on the shape

134 of response curves (mossN\% vs. N deposition). 
138 We used three subsamples of moss data in investigating the relationship of mossN\% and 139 atmospheric $\mathrm{N}$ deposition in Finland (Table 1). Forest mosses and stand TF deposition were 140 collected within the same ICP Forests Level 2 plots. Open site mosses and bulk deposition were collected from the two separate forest openings in the vicinity of each other and the

142 Level 2 forest plots within the same study area.

144 Subsample 1 (forest plots, 2009)

146 The data consists of three moss species, two feather mosses Pleurozium schreberi and 147 Hylocomium splendens, and a group of acrocarpous Dicranum species (mainly D. polysetum 148 in the south and D. polysetum, D. scoparium and D. fuscenscens in the north) collected from 14916 ICP Forests Level II plots during Jul-Aug in 2009. The moss layer was partly shaded by 150 tree canopies inside the forests (Table 2). We took 28 area based moss samples $(30 \mathrm{~cm} \times 30$ $151 \mathrm{~cm}$ ) from each plot. The samples located systematically along the four sides of the ground vegetation monitoring subplot (30 m x $30 \mathrm{~m})$, and the distance between two samples was 3-6 $\mathrm{m}$. All vegetation including ground litter and humus layer was removed as one piece and stored frozen before biomass separation in a laboratory. Some dwarf shrubs, herbs or grasses

155 grew above the moss layer in most samples.

157 All plant species were carefully separated wearing clean laboratory gloves on hands.

158 Altogether 1-8 joint samples were formed per moss species for chemical analysis. Moss thalli 159 were divided into upper green part and lower decomposing yellow-green part. The upper part 160 (length $4 \mathrm{~cm}$ ) had generally 2.5 - 3 annual growths in Jul-Aug. The samples were dried in 

(details in 2.4.). nowadays Luke).

$60^{\circ} \mathrm{C}$ temperature, weighed and grinded, and the moss $N \%$ of upper parts was determined using the CHN analyser (LECO) (Parkano lab, the Finnish Forest Research Institute, FFRI,

Subsample 2 (forest openings, 2009-2010)

This data consisted of moss samples from forest openings in the vicinity of the ICP Forests Level II plots (P. schreberi from 9 and H. splendens from 8 sites) collected as a part of "European Moss Survey" (ICP Vegetation 2010, Meyer et al. 2015). The moss samples were collected at least $10 \mathrm{~m}$ distance from the nearest trees so that TF precipitation had minimal effect on their $\mathrm{N}$ content. Altogether 4-6 moss samples were taken from different points of the open site and combined to form a sample of $2 \mathrm{~g}$ dry weight per site. Moss samples with three annual growths were dried at $35^{\circ} \mathrm{C}$, grained and mossN\% was determined using the modified micro Kjeldahl method (Kubin and Siira 1980) in the Muhos lab, FFRI. The Kjeldahl method might give slightly lower mossN\% values than LECO CHN (because it underestimates the amount of $\mathrm{NO}_{3}{ }^{-}$). However, an earlier nationwide survey of forest mossN\% in Finland (Poikolainen et al. 2009), basing on the modified Kjeldahl method, provided rather similar values for mossN\% we received by LECO CHN for forest mosses in the current study. Furthermore, the Muhos lab participated in the international quality assurance test and its results on mossN\% reference material agreed well with recommended values (Harmens et al. 2014). In the data analyses we used the average mossN\% of the samples collected monthly during May- Sep, (5 months) in 2009 or 2010. The missing moss data in some open sites was substituted by modelled values basing data from the other sites 
Moss samples (H. splendens, P. schreberi and Dicranum spp.) were collected from 10 ICP

Forests Level II plots in Jul 2002 or Aug 2003. The sampling protocol was similar as

described above for the subsample 1 . We reanalysed the total $\mathrm{N}$ concentration of stored moss

powder in 2017 and determined separately nitrite + nitrate $\left(\mathrm{NO}_{2}{ }^{-}+\mathrm{NO}_{3}{ }^{-}\right)$and $\mathrm{NH}_{4}{ }^{+}$

concentrations. For the $\mathrm{NO}_{2}{ }^{-}+\mathrm{NO}_{3}{ }^{-}$and $\mathrm{NH}_{4}{ }^{+}$analyses, $50 \mathrm{ml}$ of deionized water was added

to $0.25 \mathrm{~g}$ of ground moss. The samples were vigorously shaken by hand, after which they

were kept (horizontally) in a shaker for $16 \mathrm{~h}$ (250 rpm), centrifuged for $15 \mathrm{~min}(4000 \mathrm{rpm})$, and filtered through a $0.45-\mu \mathrm{m}$ Millipore filter (Millex HA, cellulose esters; Merck KGaA,

Darmstadt, Germany). The $\mathrm{NO}_{2}{ }^{-}+\mathrm{NO}_{3}{ }^{-}$and $\mathrm{NH}_{4}{ }^{+}$concentrations were measured with a

Thermo Scientific Gallery Plus Automated Photometric Analyser at the Lammi Biological

concentrations of moss samples were below the detection limit of the analyser $\left(<10 \mu \mathrm{g} \mathrm{l}^{-1}\right.$, i.e.

$<2 \mu \mathrm{g} \mathrm{NO}_{2}{ }^{-}+\mathrm{NO}_{3}{ }^{-}-\mathrm{N} \mathrm{g} \mathrm{g}^{-1} \mathrm{dw}$ ), the amount of water-soluble DON was calculated by subtracting $\mathrm{NH}_{4}{ }^{+}-\mathrm{N}$ from total $\mathrm{N}$.

\subsection{Precipitation, $N$ deposition measurements and $N$ leaching data}

205

Monitoring data on the amount of precipitation and chemical composition of bulk deposition

207 (BD) in the open areas was available for 14 ICP Level II plots including the outlier plot 
211 Stand TF data was available for all 16 plots. As the moss samples for chemical analysis had app. 2.5-3 annual growths, we used the corresponding three-year-period in calculating the mean annual deposition. We used the deposition period of 2007-2009 for the moss data from 2009 and 2010 (growth 2009 was unfinished in the latter year) and the periods of 2000-2002 or 2001-2003 for the moss data from 2002 and 2003, respectively. The use of three-year means diminished the effect of annual variation in the amounts of precipitation and $\mathrm{N}$ deposition. There were not increasing or decreasing temporal trends in the $\mathrm{N}_{\text {tot }}$ deposition either in BD or TF across 2000 - 2010, but annual variation in precipitation controlled the amount of N deposition in collectors (Suppl. Fig. S.1).

TF was collected within the forest stand with systematically located 20 rainfall collectors resulting in an area based estimate for the forest floor, and BD in the nearby open area with 3 rainfall collectors (funnel, diameter $20 \mathrm{~cm}$ ), during the snow-free period. During winter, 6-10 (TF) and 2 (BD) snow collectors (diameter $36 \mathrm{~cm}$ ) were used. Besides wet-deposition, the collectors probably caught some dry deposition during the 2-4 weeks collecting periods. Deposition samples were filtered (membrane filter, $0.45 \mu \mathrm{m}$ ). Total $\mathrm{N}$ was determined by flow injection analysis (FIA) (the Vantaa lab, FFRI), and $\mathrm{NH}_{4}{ }^{+}-\mathrm{N}$ and $\mathrm{NO}_{3}{ }^{-}-\mathrm{N}$ by ion chromatography (IC) (the Rovaniemi lab, FFRI), both laboratories were internationally accredited. DON deposition was calculated by subtracting the measured $\mathrm{NH}_{4}{ }^{+}-\mathrm{N}$ and $\mathrm{NO}_{3}{ }^{-}-\mathrm{N}$

230 from the total $\mathrm{N}$. The sampling procedure for the deposition measurements, including 231 laboratory analyses, is described in detail in Mustajärvi et al. (2008).

233 We used available data of the annual mass of litterfall fractions and their $\mathrm{N}$ amounts $\left(\mathrm{kg} \mathrm{ha}^{-1}\right.$ $234 \mathrm{yr}^{-1}$ ) for 11 plots (Uus23S excluded) provided by the study of Ukonmaanaho et al. (2008). 235 Based on this data, we modelled the amount of $\mathrm{N}$ in the leachate from litterfall $\left(\mathrm{kg} \mathrm{ha}^{-1} \mathrm{yr}^{-1}\right)$ 
as $6 \%$ from the total $\mathrm{N}$ in litterfall according to a short-term experiment (Aug-Sep)

237 (Ukonmaanaho and Starr 2001).

238

\section{Data analysis}

We used area based $\mathrm{N}$ deposition values $\left(\mathrm{kg} \mathrm{ha}^{-1} \mathrm{yr}^{-1}\right)$ consisting of information on both the $\mathrm{N}$ concentration in precipitation and amount of precipitation in the data analysis. The amount of $\mathrm{N}_{\text {tot }}$ in BD and TF within the study areas (open site vs. forest site) and the amount of $\mathrm{NH}_{4}{ }^{+}-\mathrm{N}$ and $\mathrm{NO}_{3}{ }^{-}-\mathrm{N}$ within $\mathrm{BD}$ and $\mathrm{TF}$ were compared by paired t tests. Furthermore, we tested the effect of zone (north, south) and tree species on the amount of DON in TF using ANOVA and post-hoc Tukey's t-tests.

We calculated open site/forest site mossN\% ratios to nine study areas having moss samples from the both habitats. Then we modelled the missing mossN\% values for open sites (five open sites in $H$. splendens and seven in $P$. schreberi) by multiplying forest mossN\% values using this ratio (cf. Meyer et al. 2015). We used tree-species specific average ratios for $P$. schreberi and the overall average for $H$. splendens.

We used four-factor ANOVA in testing the effect of moss species (P. schreberi, $H$. splendens), habitat (open site, forest), zone (northern, southern part of the country) and dominant tree species (pine, spruce) and their two-factor interactions on the mossN\% (13 plots with two coexisting moss species). Similarly, we used three-factor ANOVA in testing the effect of moss species (three coexisting species in forest habitat), zone and tree species and their two-factor interactions on mossN\% (13 forest plots, 2009) and on free $\mathrm{NH}_{4}{ }^{+}-\mathrm{N}$ concentration in moss tissues (10 forest plots, 2002-2003). Pairwise comparisons between 
the moss species after ANOVA were made by post-hoc Tukey's t-tests. Assumption of

262

263 normal distribution of the data in using parametric tests was checked by Shapiro-Wilk normality tests and the data was $\log (x+1)$ transformed when needed. We analysed the relationship between the averages of moss $\mathrm{N} \%$ and amount of $\mathrm{N}$ leachate calculated separately to the pine and spruce stands in the north and south using Spearman rank correlation. The tests were carried out using the STATISTIX 10.0 program (2013).

We fitted linear logarithmic models $(\mathrm{lm})$ for the three moss species in order to study the response of mossN\% ( $\mathrm{y}$ variable) to different $\mathrm{N}$ forms in deposition ( $\mathrm{x}$ variable). Separate species-specific models were calculated for moss $\mathrm{N} \%$ in open site vs. $\mathrm{BD}$, and for mossN\% in forest site vs. TF. We used total $\mathrm{N}\left(\mathrm{N}_{\text {tot }}=\mathrm{NH}_{4}{ }^{+}-\mathrm{N}+\mathrm{NO}_{3}{ }^{-} \mathrm{N}+\mathrm{DON}\right)$, inorganic $\mathrm{N}\left(\mathrm{N}_{\text {inorg }}=\right.$ $\mathrm{NH}_{4}{ }^{+}-\mathrm{N}+\mathrm{NO}_{3}{ }^{-}-\mathrm{N}$ ) or individually $\mathrm{NH}_{4}{ }^{+}-\mathrm{N}, \mathrm{NO}_{3}{ }^{-}-\mathrm{N}$ and DON as explanatory variables. Interaction between $\mathrm{N}_{\text {inorg }}$ and DON, tree species (pine, spruce) and $\mathrm{N}_{\text {tot }}$, as well as DON and stand basal area were tested. We answered the hypothesis arguing DON contributes significantly to moss $\mathrm{N} \%$ in forest habitats by comparing two models, the first having only $\mathrm{N}_{\text {inorg }}$ as a predictor, and the second having both $\mathrm{N}_{\text {inorg }}$ and DON as predictors of the mossN\%. Linear logarithmic models (lm) were used also in analysing the response of $\mathrm{NH}_{4}^{+}-$ $\mathrm{N}$ and total $\mathrm{N} \%$ of tissues of feathermosses (average of H. splendens and P. schreberi) to increasing $\mathrm{N}_{\text {tot }}$ in TF deposition (data 2002-2003).

Finally, we studied how well $\mathrm{N}_{\text {tot }}$ deposition (y) in background forests in Finland could be predicted according to moss $\mathrm{N} \%$ of the three moss species (x). We made separate $1 \mathrm{~m}$ logarithmic models for open site (BD vs. feather mosses) and forest site (TF vs. feather mosses and Dicranum spp.) data. We used the species-specific as well as average mossN\% values of $H$. splendens and $P$. schreberi as predictors in the models. The goodness of fit was 
evaluated according to adjusted $\mathrm{R}^{2}$ values in all models. We used the $\mathrm{R}$ statistical environment in constructing the models ( $\mathrm{R}$ core team 2017).

288

289

290

4. Results

291

292

4.1. Amount and chemistry of $N$ deposition and $N$ leachate from litterfall

293

294

The $\mathrm{N}_{\text {tot }}$ in BD increased from 1.2 to $4.8 \mathrm{~kg} \mathrm{ha}^{-1} \mathrm{yr}^{-1}$ along the latitudinal gradient from north 295 to south (Fig. 2a, Table S.1). The $\mathrm{N}_{\text {tot }}$ was higher in BD than in $\mathrm{TF}(\mathrm{p}<0.01)$, but the average difference was smaller in the north $\left(0.3 \mathrm{~kg} \mathrm{ha}^{-1} \mathrm{yr}^{-1}, \mathrm{p}<0.05\right)$ than in the south $\left(0.8 \mathrm{~kg}^{-1} \mathrm{ha}^{-1}\right.$ $\mathrm{yr}^{-1}, \mathrm{p}<0.01$ ). The absolute (Fig. 2a,b) and relative amounts (Fig. S.2a,b) of different $\mathrm{N}$ forms varied between $\mathrm{BD}$ and TF. In $\mathrm{BD}$, the proportion of $\mathrm{N}_{\text {inorg }}$ was $70-85 \%$ of $\mathrm{N}_{\text {tot }}$, whereas in TF it was ca. $60 \%$ in the north and only $40 \%$ in the southernmost plots. The amount of $\mathrm{NO}_{3}^{-}-$ $\mathrm{N}$ was higher than that of $\mathrm{NH}_{4}{ }^{+}-\mathrm{N}$ in both $\mathrm{BD}$ and $\mathrm{TF}(\mathrm{p}<0.001)$. Only in the outlier plot Uus23S (excluded from the tests above) $\mathrm{NH}_{4}{ }^{+}-\mathrm{N}$ was remarkable higher than $\mathrm{NO}_{3}{ }^{-} \mathrm{N}$ in $\mathrm{TF}$ (Fig. 2b). The amount of DON increased from north to south in TF, and it was higher in spruce than pine stands in the south $(\mathrm{p}<0.05)$ (Table S.2a-c). The amount of $\mathrm{N}$ leached from the tree litter varied from $0.3-0.6 \mathrm{~kg} \mathrm{ha}^{-1} \mathrm{yr}^{-1}$ in the north and from $0.7-2.3 \mathrm{~kg} \mathrm{ha}^{-1} \mathrm{yr}^{-1}$ in 305 the south (Fig. 2c).

4.2. Effect of site, zone, tree species and litterfall on mossN\% northern part of the country $(\mathrm{p}<0.05)$ (Fig. 3a, Table 2), and in spruce than pine stands 
311 (p<0.05) (Fig. 3b). H. splendens and P. schreberi had similar average mossN\% values, but

312 Dicranum spp. had higher mossN\% than the feather mosses in forests $(p<0.05)$. The average

313 mossN\% of $P$. schreberi and $H$. splendens was higher in forest (range $0.8-1.7 \%$ ) than in open

314 site habitats $(0.5-1.2 \%)$ both in pine and spruce dominated areas $(\mathrm{p}<0.001)$ (Fig. 3a,b). The

315 mossN\% of feather mosses was higher in spruce than pine dominated areas also in open site

316 habitats in the southern part of country $(p<0.05)$ (Fig. 3b, for ANOVA see Table S.3a,b).

317 Moreover, the mossN\% of feather mosses tended to increase with increasing amount of N

318 leachate from litterfall $(\mathrm{p}<0.08)$ when compared as average values in pine and spruce stands

319 in the south and north. The outlier plot Uus23S was not included in the data analysis

320 presented here.

321

322

4.3. Response of moss $N \%$ to total $N$ deposition at open and forest sites

323

324 In the open sites, the mossN\% of both feather moss species increased almost linearly with

325 increasing $\mathrm{N}_{\text {tot }}$ in $\mathrm{BD}$ (Fig. 4a,b). The $\mathrm{R}^{2}$ value of the open site model (mod1B) was higher

326 for P. schreberi (81\%) than for H. splendens (52\%) (Table 3a,b). Similarly, the mossN\% of

327 both feather moss species and Dicranum spp. sampled from forests increased with increasing

$328 \mathrm{~N}_{\text {tot }}$ in stand TF (Fig. 4a-c). However, here the response followed an asymptotic curve

329 showing a slight decrease in the $\mathrm{N}$ accumulation rate at higher $\mathrm{TF} \mathrm{N}_{\text {tot }}$ levels. $\mathrm{R}^{2}$ value for $P$.

330 schreberi (73\%) was higher than those for H. splendens (60\%) and Dicranum spp. (54\%) in

331 the mod1TF equations (Table 3a-c). When the outlier plot Uus23S was included to these

332 models, the shape of the curves did not change compared to the basic models without Uus23S

333 (Fig. 4a-c; for Model tables see Suppl. Table S.4a,b). For P. schreberi the fit of the mod1B

334 was higher $\left(\mathrm{R}^{2} 81 \%\right)$ than that of $\bmod 1 \mathrm{TF}(73 \%)$, but opposite was true for $H$. splendens

335 (Table 3a,b). 
339 The dominant tree species (pine or spruce) surrounding the forest openings had no

340 statistically significant effect when added as the second predictor with $\mathrm{N}_{\text {tot }}$ in the models of

341 feather mosses $(\bmod 2 \mathrm{~B}$, Table 3a,b). However, mossN\% (especially in H. splendens) tended

342 to increase higher with increasing $\mathrm{N}_{\text {tot }}$ deposition in openings surrounded by spruce than by

343 pine in the southern part of the country (Fig. S.3). Similar effect of the tree species was found

344 in forest sites. Here interaction between $\mathrm{N}_{\text {tot }}$ and tree species $(\mathrm{p}<0.06-0.08)$ in equations of

345 P.schreberi and Dicranum spp. $(\bmod 2 \mathrm{TF})$ showed higher accumulation rate of mossN\% in

346 spruce than in pine dominated stands (Table 3a-c, Fig. S.3).

347

4.3.2. Moss $N \%$ in relation to different forms of $N$ deposition and stand basal area

349

$350 \mathrm{~N}_{\text {inorg }}$ of $\mathrm{BD}$ explained most variation in mossN\% of the both feather moss species in forest

351 openings in one-predictor models $(\bmod 6 \mathrm{~B})$. Adding DON of BD as the second predictor was

352 not significant and did not increase the $\mathrm{R}^{2}$ values of the models $(\bmod 7 \mathrm{~B})($ Table $3 \mathrm{a}, \mathrm{b})$. On the

353 other hand, $\mathrm{N}_{\text {inorg }}$ of TF in forest sites had relatively low $\mathrm{R}^{2}$ values $(21-39 \%)$ in one-

354 predictor models (mod6TF) for all three moss species, whereas TF DON as the second

355 predictor was highly significant $(\mathrm{p}<0.01)$ and it explained most variation in mossN\%

356 (mod7TF, Table 3). When TF DON was included to the models, TF $\mathrm{N}_{\text {inorg }}$ changed to be an

357 insignificant predictor. There was no interaction between $\mathrm{N}_{\text {inorg }}$ and DON in either BD or TF

358 models (not shown). However, the effect of TF DON on mossN\% was controlled by the

359 forest structure, being higher in the stands with larger basal area (significant interaction

360 DON: Basal area in modTF8 in all moss species) (Table 4, Fig.S.4). In the case of $P$. 
schreberi also $\mathrm{N}_{\text {inorg }}$ had a small positive effect $(\mathrm{p}<0.10)$ on mossN\% when the effect of DON

362

363

364 The distinct effects of DON in open and forest sites are clearly seen in the shape of the

365 response curves of mossN\% vs $\mathrm{N}$ form (Fig. 4a-c). The range of DON (on $\mathrm{x}$ axis) in the

366

367

368

369

372

373

374

375

376

377

378

379

380

381

382

383

384

was linked in the interaction term with basal area. forest sites was twice as wide as that in the open sites. Thus, in the open sites the effect of DON on mossN\% was minimal whereas $\mathrm{N}_{\text {inorg }}$ dominated the $\mathrm{N}_{\text {tot }}$ deposition pattern. On the other hand, DON determined the shape of mossN\% vs. $\mathrm{N}_{\text {tot }}$ curve in the forest sites. The location of the outlier plot Uus23S was distant from the response curves of mossN\% vs BD in the open sites, but it fitted quite well to the curves of mossN\% vs. TF $\mathrm{N}_{\text {tot }}$ or $\mathrm{TF} \mathrm{N}_{\text {inorg }}$ based on the forest data (Fig. 4a-c).

\subsection{Free $\mathrm{NH}_{4}-\mathrm{N}$ in moss tissues (forest data 2002-2003)}

An analysis of $\mathrm{N}$ forms in mosses collected from the forest plots (2002-2003) showed that most $\mathrm{N}$ (average $98.8 \%$ ) was assimilated into organic $\mathrm{N}$ compounds. However, we found a small amount of free $\mathrm{NH}_{4}{ }^{+}-\mathrm{N}(1.2 \%)$ in tissues. The concentration of $\mathrm{NH}_{4}{ }^{+}-\mathrm{N}$ was higher in the southern than in northern stands $(\mathrm{p}<0.001)$, and in spruce than in pine stands $(\mathrm{p}<0.001)$ in each three moss species (Suppl. Fig. S.5, Table S.3c). Average $\mathrm{NH}_{4}{ }^{+}-\mathrm{N}$ as well as total $\mathrm{N}$ concentration of the feather mosses increased with increasing TF $\mathrm{N}_{\text {tot }}$ deposition according to an asymptotic curve (Fig. 5, Table S.5).

\subsection{Predicting $N_{\text {tot }}$ deposition for background forest areas by mossN\%}


385 Equations predicting the $\mathrm{N}_{\text {tot }}$ deposition in background forests of Finland according to average mossN\% of the feather moss species gave high fit for both open $\left(\mathrm{R}^{2}=73 \%\right)$ and forest

387 site habitats $\left(\mathrm{R}^{2}=79 \%\right.$ ) (Fig. 6, Suppl. Table S.6). P. schreberi predicted slightly higher BD

$388 \mathrm{~N}_{\text {tot }}$ estimates than $H$. splendens for open sites, but the TF $\mathrm{N}_{\text {tot }}$ estimates of the two species

389 were almost similar for forest sites. Dicranum spp. predicted lower TF $\mathrm{N}_{\text {tot }}$ than feather 390 mosses for forests.

391

392

\section{5. Discussion}

395 We found clear positive relationship between the mossN\% of and $\mathrm{N}_{\text {tot }}$ deposition in background forest areas along an extensive north-south gradient in Finland. The $\mathrm{N}_{\text {tot }}$ deposition was lower in forest TF than in open site BD, indicating that tree canopies filtered and absorbed dry and wet-deposited $\mathrm{N}$ in northern N-limited forests (Mustajärvi et al. 2008).

399 On the other hand, mossN\% was higher within forest stands than in forest openings.

400 Corresponding difference in mossN\% concentrations between the two types of growing sites has also been observed in Slovenia (Skudnik et al. 2014) and in Germany (Kluge et al. 2013, Meyer et al. 2015), but there - unlike in Finland $-\mathrm{N}_{\text {tot }}$ deposition was much higher in forests 403 (rich with $\mathrm{NH}_{4}{ }^{+}-\mathrm{N}$ and $\mathrm{NO}_{3}{ }^{-}-\mathrm{N}$ ) than in open sites. The possible reasons for the observed 404 mossN\% pattern in our study are: (1) Mosses prefer certain forms of $\mathrm{N}$ (e.g. amino acids in 405 DON) the amounts of which are higher in TF than in BD (cf. Harmens et al. 2014); (2) a part of $\mathrm{N}$ accumulating in mosses originates from $\mathrm{N}$ leachates of litterfall (Ukonmaanaho and

407 Starr 2001) not included in BD or TF; (3) biological $\mathrm{N}_{2}$ fixation of moss-associated bacteria 408 (Salemaa et al. 2019); (4) translocation of N from senescing tissues to new moss growth 409 (Eckstein and Karlsson 1999, Salemaa et al. 2008), and (5) differences in moss growth rates 
due to differences in abiotic and biotic factors between geographical areas and forest types

411 (Harmens et al. 2011).

412

413

\subsection{The effect of different $N$ forms on moss $N \%$}

414

415 Our results suggested that differences in the deposition chemistry and supply of different $\mathrm{N}$

416 forms between the open and forest sites affected the uptake of $\mathrm{N}$ from precipitation by

417 mosses. At the open sites inorganic forms of $\mathrm{N}$ in deposition explained the accumulation of $\mathrm{N}$

418 in mosses, whereas DON explained almost completely the variation of mossN\% in forest

419 sites. These correlative results gave indirect evidence for moss affinity to DON and supported

420 the hypothesis that the canopy drip of DON greatly contributed to mossN\% in forests.

421 However, mosses seemed to have an ability to absorb both inorganic and organic $\mathrm{N}$ forms

422 depending on the region and stand structure. $\mathrm{NH}_{4}{ }^{+}-\mathrm{N}$ and $\mathrm{NO}_{3}{ }^{-}-\mathrm{N}$ in $\mathrm{BD}$ correlated positively

423 with mossN\%, but it is difficult to conclude which inorganic $\mathrm{N}$ form was preferred by mosses

424 based on the correlative approach. The effect of $\mathrm{N}_{\text {inorg }}$ also in forest site was observed in the 425 outlier 'fox farm' plot (Uus23S), where the annual $\mathrm{NH}_{4}{ }^{+}-\mathrm{N}$ deposition was $3.3 \mathrm{~kg} \mathrm{ha}^{-1}$ higher 426 in TF than in BD most probably because dry-deposited $\mathrm{NH}_{3}$ and $\mathrm{NH}_{4}{ }^{+}$were washed down

427 from the spruce canopy. Here the mossN\% of $P$. schreberi was $2.2 \%$ in forest and $1.4 \%$ in 428 opening.

430 Depending on the conditions, amino acids in DON may contribute substantially to $\mathrm{N}$ sequestration of mosses (Wiedermann et al. 2009, Liu et al. 2013) although they only account

432 for a small proportion of the bioavailable fraction of DON (Neff et al. 2002). DON usually 433 accounts for about 20 to $65 \%$ of total $\mathrm{N}$ in wet deposition (Cornell et al. 2003). In the Finnish 434 background forests, DON formed nearly a half (>40\%) of the $\mathrm{N}_{\text {tot }}$ in TF, whereas its share 
was only $20 \%$ in BD. We did not analyse the composition of DON, but mosses apparently took up amino acids, such as glycine (Song et al. 2016), as they can be absorbed easily into moss cells through cation exchange capacity and proton $\left(\mathrm{H}^{+}\right)$pump (Glime et al. 2007).

\subsection{The effect of tree species and stand basal area on mossN\%}

The average mossN\% of the studied moss species was higher in spruce than in pine stands. Furthermore, the accumulation rate of $\mathrm{N}$ in mosses in relation to $\mathrm{N}_{\text {tot }}$ was slightly higher under the spruce than pine canopies and increased with increasing stand basal area. Both the characteristics of tree species and the site fertility regulated the composition of $\mathrm{TF}$ in forests. Especially in the southern spruce stands, tree canopies modified the N in TF so that DON leached from the canopies compensated the inorganic $\mathrm{N}$ retained therein (Mustajärvi et al. 2008). The greater needle mass (i.e. greater leaf area) of southern spruce stands in comparison to those of pine (Merilä et al. 2014) enable spruce crowns to capture more $\mathrm{N}_{\text {inorg }}$ from dry and wet deposition than pine crowns. In addition, the higher fertility level of spruce dominated site types (Tamminen 2000, Lukina et al. 2018) may result in larger amount of DON leaching in TF in spruce than in pine stands. $\mathrm{N}_{\text {inorg }}$ in TF explained the mossN\% of $P$. schreberi at forest sites when interaction term DON:basal area was included in the model. This is reasonable particularly in northern stands which are sparser and have smaller canopy coverage (Table 2) in comparison to southern stands. It is noteworthy, that tree species of the surrounding forest also tended to influence mossN\% in open site models in the southern part of the country, although the sampling plots were treeless. This kind of tree effect may be caused by litterfall or the fertility level of the site. 
460 Aboveground litterfall (shed leaves, branches and bark) of trees and understorey vegetation is

461 an important pathway of nutrient return in the forest ecosystem. According to Ukonmaanaho

462 et al. (2008) $\mathrm{N}$ return from needle litter of coniferous stands is ca. 5 and $7-14 \mathrm{~kg} \mathrm{~N} \mathrm{ha}^{-1} \mathrm{yr}^{-1}$

463 in the northern and in the southern Finland, respectively. During autumn and winter, litterfall

464 enter new decomposable material and water-extractable $\mathrm{N}$ on the forest floor (Ukonmaanaho

465 and Starr 2001, Hilli et al. 2008). As predicted, the modeled estimates for the amount of N

466 leachate for our forest plots tended to show a positive relationship with mossN\% at the

467 regional scale. $\mathrm{N}$ leachate contributes to internal cycling of $\mathrm{N}$ in forests and it may partly

468 explain the higher mossN\% at forest than at open sites.

469

470 In a previous study carried out partly in the same forest plots as the present study, the activity

471 of cyanobacteria hosted by mosses was highest in the northern plots having low $\mathrm{N}$ deposition,

472 and ceased in the south (Salemaa et al. 2019). Because light level regulates the activity of

473 cyanobacteria, it is probable that $\mathrm{N}_{2}$ fixation is higher in mosses growing at open than forest

474 sites. In contrast, $\mathrm{N}$ translocation to the new growth of mosses may be faster in moist

475 conditions expressing as higher mossN\% in forests than at open sites.

476

477 5.4. The impact of low $N$ deposition on mossN\%

478

479 Large-scale European data has provided evidence of asymptotic relationship between the mossN\% and $\mathrm{N}$ deposition (Harmens et al. 2014). The data from Finland (open site data of $P$. schreberi, also used in our study) represented background areas with the lowest bulk $\mathrm{N}$ deposition. The Finnish data was within the initial linear part of the asymptotic response curve and showed a good fit with the model. The models of all three moss species at open 
sites had high $\mathrm{R}^{2}$ values also in the current analyses. The best fit was found for the

485 relationship between $\mathrm{N} \%$ of $P$. schreberi and the amount of $\mathrm{N}_{\text {inorg }}$ in $\mathrm{BD}\left(\mathrm{R}^{2}=82 \%\right)$.

486 Similarly, in a Swiss study by Kosonen et al. (2018) mossN\% of P. schreberi and Hypnum

487 cupressiforme showed a good relationship with $\mathrm{N}$ originating from dry deposited $\mathrm{NH}_{3}$ and

488 from precipitation (DON excluded; $\mathrm{R}^{2}=81 \%$ ). The mossN\% was generally slightly higher in

489 Switzerland than in Finland, probably due to the higher contribution of dry-deposited $\mathrm{NH}_{3}$ to 490 mossN\% at the Swiss sites (Kosonen et al. 2018).

491

492 Overall, bulk sampler measurements include only a part of the total amount of the reactive $\mathrm{N}$ 493 included in fine particles and gases incorporated on foliar surfaces of plants i.e., the sampling 494 method overestimate wet deposition but underestimate dry deposition (Loubet et al. 2009, 495 Meyer et al. 2015). Our sample plots (except one outlier) were located in background areas 496 far from agricultural and livestock sites and roads, and therefore the amount of dry deposition 497 on the plots was most probably low. On the other hand, in natural boreal ecosystems, both 498 low temperatures and rainfall limit the ability of mosses to assimilate excess $\mathrm{N}_{\text {inorg }}$ and to 499 allocate it into new biomass.

500

501 In the response models of the joint European data the mossN\% did not greatly respond to 502 increasing $\mathrm{NH}_{4}{ }^{+}-\mathrm{N}$ deposition of over $12 \mathrm{~kg} \mathrm{ha}^{-1} \mathrm{yr}^{-1}$, and wet bulk $\mathrm{N}$ deposition of over 20 $503 \mathrm{~kg} \mathrm{ha}^{-1} \mathrm{yr}^{-1}$ (Harmens et al. 2014). According to Pitcairn et al. (1998) mossN\% is saturated to 504 a level of ca. $2 \%$ when the wet BD is ca. $20 \mathrm{~kg} \mathrm{~N} \mathrm{ha}^{-1} \mathrm{yr}^{-1}$. However, Pitcairn et al. (2006) 505 concluded mosses cannot reach high $\mathrm{N}$ concentrations in the field conditions when 506 precipitation is high, unless rainfall constantly contains large concentrations of N. In Finland,

$507 \mathrm{~N}_{\text {tot }}$ deposition is remarkably lower than the $\mathrm{N}$ levels mentioned above. At open sites the 508 relationships between mossN\% and $\mathrm{N}_{\text {tot }}$ in $\mathrm{BD}$ were linear and the highest mossN\% was $1-$ 
510 deposition was only $3-5 \mathrm{~kg} \mathrm{ha}^{-1} \mathrm{yr}^{-1}$ and the highest moss $\%$ c.a. $1.4-2.0 \%$. Also free

$511 \mathrm{NH}_{4}{ }^{+}-\mathrm{N}$ accumulated in mosses in the southern forests at this $\mathrm{N}$ deposition level suggesting

512 mosses were near the $\mathrm{N}$ saturation state at these sites. Thus, our data suggests that the boreal

513 mosses were achieving the $\mathrm{N}$ saturated state at much lower level than $20 \mathrm{~kg} \mathrm{ha}^{-1} \mathrm{yr}^{-1} \mathrm{when}$

514 growing under the effects of tree canopies and litterfall.

515

516

\subsection{Predicting N deposition based on mossN\%}

517

518 The nationwide surveys on mossN\% in H. splendens in Finland reflected well the known

519 decreasing gradient of $\mathrm{N}$ deposition from south to north at the country level, but the correlation with the modelled $\mathrm{N}$ deposition was fairly weak (Poikolainen et al. 2009). The authors suggested that in addition to $\mathrm{N}$ deposition, the variability in a range of site and stand characteristics cause variation in moss $N \%$. In the present study, we were able to quantify the relationship between moss $\mathrm{N} \%$ and $\mathrm{N}_{\text {tot }}$ in more detail because $\mathrm{N}$ deposition was measured at the moss sampling sites (TF) or in their vicinity (BD).

525

526 At open sites, the linear pattern of accumulation of $\mathrm{N}$ in mosses with increasing $\mathrm{N}_{\text {tot }}$

527 deposition gives evidence of their high bio-indicator value at conditions of fairly low $\mathrm{N}$

528 deposition. This finding justifies using the open site equations in modelling $\mathrm{N}_{\text {dep }}$ particularly

529 in remote boreal areas, where it is not possible to maintain continuous $\mathrm{N}_{\text {dep }}$ monitoring

530 systems. Mosses growing in forests took up $\mathrm{N}$ from TF precipitation passing tree and dwarf

531 shrub canopies and from litterfall. Because these processes are controlled by many

532 environmental factors (e.g. stand structure, amount of dry deposition and precipitation, and

533 temperature), we recommend using the equations calculated from the open site data. We also 
recommend using $P$. schreberi in field studies when possible because its equations showed the best fit between the moss $\%$ and $\mathrm{N}$ deposition at both open and forest sites.

536

\section{Conclusions}

539 Given the low precipitation and low $\mathrm{N}$ deposition at the Finnish sites as well as higher 540 mossN\% in forests than in openings, it is probable that TF at background sites was enriched 541 with $\mathrm{N}$ forms (e.g. amino acids in DON) readily taken up by mosses. This was reflected as a 542 lowered $\mathrm{N}$ uptake efficiency of mosses at higher $\mathrm{N}$ exposure levels. The view is supported by 543 the asymptotic form of the accumulation curves of the $\mathrm{N}_{\text {tot }}$ and $\mathrm{NH}_{4}-\mathrm{N}$ in tissues vs. $\mathrm{N}$

544 deposition, suggesting mosses in forests were approaching $\mathrm{N}$ saturation at TF $\mathrm{N}_{\text {tot }}$ of $3-4 \mathrm{~kg}$

$545 \mathrm{ha}^{-1} \mathrm{yr}^{-1}$. Corresponding level of $\mathrm{N}$ deposition has been found to turn off $\mathrm{N}_{2}$ fixation of 546 cyanobacteria associated with mosses (Salemaa et al 2019). The accumulation of $\mathrm{NH}_{4}{ }^{+}-\mathrm{N}$ in 547 moss tissue may indicate that the supply of $\mathrm{N}_{\text {inorg }}$ exceeds the ability of mosses to assimilate 548 and allocate $\mathrm{N}$ into biomass production i.e. the moss growth is no longer $\mathrm{N}$ limited. However, 549 it should be noted that a part of the $\mathrm{N}$ accumulated in mosses apparently came from the $\mathrm{N}$ 550 leachate from litterfall emphasizing the effect of internal $\mathrm{N}$ flux of the forest ecosystem. 551 According to Bobbink et al. (2010) and Bobbink and Hettelingh (2011) critical N load for 552 eutrophication, i.e. slow changes in the structure and function of boreal forests, may take 553 place already at $\mathrm{N}$ deposition levels $<5 \mathrm{~kg} \mathrm{ha}^{-1} \mathrm{yr}^{-1}$. This level is near the suggested $\mathrm{N}$

554 saturation point of the boreal mosses in our study. However, more research is needed for 555 understanding what kind of roles mosses have in the internal $\mathrm{N}$ flux and eutrophication 556 process of boreal ecosystems. 
560 The study was co-funded by EU Life+ FutMon project and by the Academy of Finland

561 financed (A-J K: decision nrs. 296116 and 307192). We greatly acknowledge the contribution

562 of Luke's field and laboratory staff to this study. Ms. Riitta Ilola and Mr. Jaakko Vainionpää

563 are thanked for performing the moss $\mathrm{NH}_{4}{ }^{+}-\mathrm{N}$ and $\mathrm{NO}_{2}{ }^{-}+\mathrm{NO}_{3}{ }^{-}-\mathrm{N}$ analyses (University of

564 Helsinki).

565

566

567 Appendix: Supplementary Figures and Tables 
569

570

571

572

573

574

575

576

577

578

579

580

581

582

583

584

585

586

587

588

589

590

591

592

\section{References}

Ayres E., van der Wal R., Sommerkorn M., Bardgett R.D., 2006. Direct uptake of soil nitrogen by mosses. Biology Letters 2, 286-288. http://doi.org/10.1098/rsbl.2006.0455

Bernhardt-Römermann, M., Baeten, L., Craven, D., De Frenne, P., Hédl, R., Lenoir, J., ... \& Dierschke, H., 2015. Drivers of temporal changes in temperate forest plant diversity vary across spatial scales. Global Change Biology, 21(10), 3726-3737. https://doi.org/10.1111/gcb.12993

Bobbink, R., Hicks, K., Galloway, J., Spranger, T., Alkemade, R., Ashmore, M., ... \& Emmett, B., 2010. Global assessment of nitrogen deposition effects on terrestrial plant diversity: a synthesis. Ecological applications, 20(1), 30-59. http://doi.org/10.1890/08-1140.1

Bobbink R., Hettelingh J.P. (Eds.), 2011. Review and revision of empirical critical loads and dose-response relationships, Coordination Centre for Effects, National Institute for Public Health and the Environment (RIVM). www.rivm.nl/cce Chapin III F.S., Moilanen L., Kielland K., 1993. Preferential use of organic nitrogen for growth by a non-mycorrhizal arctic sedge. Nature 361, 150-153.

Cornell S.E., Jickells T.D., Cape J.N., Rowland A.P., Duce R.A. 2003. Organic nitrogen deposition on land and coastal environments: a review of methods and data. Atmospheric Environment 37, 2173-2191. https://doi.org/10.1016/S13522310(03)00133-X

De Schrijver A., Geudens G., Augusto L., Staelens J., Mertens J., Wuyts K., Gielis L., Verheyn K., 2007. The effect of forest type on throughfall deposition and seepage 
605

606

607

608

609

610

611

612

613

614

615

616

flux: a review. Oecologia 153, 663-674. https://doi.org/10.1007/s00442-0070776-1

Dirnböck, T., Pröll, G., Austnes, K....\& Forsius, M.; 2018. Currently legislated decreases in nitrogen deposition will yield only limited plant species recovery in European forests. Environmental Research Letters 13: 12. https://doi.org/10.1088/17489326/aaf26b

Eckstein, R.L., Karlsson, P.S., 1999. Recycling of nitrogen among segments of Hylocomium splendens as compared with Polytrichum commune: implications for clonal integration in an ectohydric bryophyte. Oikos, 86, 87-96.

Erisman, J.W., Bleeker, A., Galloway, J., Sutton; M.S., 2007. Reduced nitrogen in ecology and the environment. Environmental Pollution 150, 140-149. https://doi.org/10.10.1016/j.envpol.2007.06.033

Forsum, Å., Dahlman, L., Näsholm, T., Nordin, A., 2006. Nitrogen utilization by Hylocomium splendens in a boreal forest fertilization experiment. Functional Ecology 20, 421-426. https://doi.org/10.1111/j.1365-2435.2006.01127.x

Fowler D., Cape J.N., Coyle M., Flechard C., Kuylenstierna J., Hicks K., Derwent D., Johnson C., Stevenson D. 1999. The global exposure of forests to air pollutants. Water, Air, and Soil Pollution 116, 5-32. https://doi.org/10.1023/A:1005249231882

Galloway,J. N., Dentener,F. J., Capone D. G., Boyer E. W., Howarth R. W., Seitzinger S. P., Asner G. P., Cleveland C. C., Green P. A., Holland E. A., Karl D. M., Michaels A. F., Porter J. H., Townsend A. R., Vöosmarty,C. J., 2004. Nitrogen cycles: past, present, and future. Biogeochemistry 70, 153-226. https://doi.org/10.1007/s10533004-0370-0

Glime J.M., 2007. Bryophyte Ecology. Michigan, Michigan Technological University and the International Association of Bryologists. http://www.bryoecol.mtu.edu 
618 Harmens H., Norris D.A., Cooper D.M., et.al., 2011. Nitrogen concentrations in mosses

619

620

621

622

623

624

625

626

627

628

629

630

631

632

633

634

635

636

637

638

639

640

641 indicate the spatial distribution of atmospheric nitrogen deposition in Europe. Environmental Pollution 159, 2852-2860.

https://doi.org/10.1016/j.envpol.2011.04.041

Harmens H., Schnyder E., Thöni L.,Cooper D.M., Mills G., Leblond S., Mohr K., Poikolainen J., Santamaria J., Skudnik M., Zechmeister H.G., Lindroos A.-J., Hanus-Illnar, A., 2014. Relationship between site-specific nitrogen concentration in mosses and measured wet bulk atmospheric nitrogen deposition across Europe. Environmental Pollution 194, 50-59. https://doi.org/10.1016/j.envpol.2014.07.016

Hawkins B.J., May, E., Robbins, S., 2018. Nitrate and ammonium uptake in 21 common species of moss from Vancouver Island, British Columbia. Botany 96, 201-208, https://doi.org/10.1139/cjb-2017-0154.

Hilli, S., Derome, J., 2008. Water-extractable organic compounds in different components of the litter layer of boreal forest soils along a climatic gradient. Boreal Environment Research 13 (suppl. B): 92-106.

Izquieta-Rojano S., García-Gomez H., Aguillame L., Santamaría J.M., Tang Y.S., Santamaría C., Valiño F., Lasheras E., Alonso R., Àvila A., Cape J.N., Elustondo D., 2016. Throughfall and bulk deposition of dissolved organic nitrogen to holm oak forests in the Iberian Peninsula: Flux estimation and identification of potential sources. Environmental Pollution 210, 104-112. https://doi.org/10.1016/j.envpol.2015.12.002

Kielland K. 1997. Role of free amino acids in the nitrogen economy of arctic cryptogams. Ecoscience 4, 75-79 https://doi.org/10.1080/11956860.1997.11682379 
642 Kluge M., Pesch R., Schröder W., Hoffmann A., 2013. Accounting for canopy drip effects

643

644

645

646

647

648

649

650

651

652

653

654

655

656

657

658

659

660

661

662

663

664

665 of spatiotemporal trends of the concentrations of $\mathrm{N}$ in mosses, atmospheric $\mathrm{N}$ depositions and critical load exceedances: a case study from North-Western Germany. Environmental Sciences Europe 25, 26. https://link.springer.com/article/10.1186/2190-4715-25-26

Kosonen Z., Thimonier A., Schnyder E., Thöni L., 2018. Nitrogen concentration in moss compared with $\mathrm{N}$ load in precipitation and with total $\mathrm{N}$ deposition in Switzerland. Environmental Pollution 239, 169-178. https://doi.org/10.1016/j.envpol.2018.03.063

Kubin, E., Siira, J., 1980. On the suitability of the phenyl hypochlorite procedure for the determination of total nitrogen from plant and soil samples. Aquilo Ser. Botanica $17,11-17$.

Liu X.-Y., Koba K., Makabe A., Li X.-D., Yoh M., Liu C.-Q., 2013. Ammonium first: natural mosses prefer atmospheric ammonium but vary utilization of dissolved organic nitrogen depending on habitat and nitrogen deposition. New Phytologist 199, 407-419. https://doi.org/10.1111/nph.12284

Loubet B., Asman W.A.H., Theobald M.R., Hertel O., Sim Tang Y., Robin P., Hassouna M., Dämmgen U., Genermont S., Collier P., Sutton M.A., 2009. Ammonia deposition neat hot spots., in: Sutton M.A., Reis S., Baker, S.M.H. (Eds.), Atmospheric Ammonia. Springer, The Netherlands, pp. 205-267.

Lovett G.M., Lindberg S.E. 1993. Atmospheric deposition and canopy interactions of nitrogen in forests. Canadian Journal of Forest Research 23, 1603-1616.

Lukina, N.V., Orlova, M.A., Bakhmet, O.N., Tikhonova, E.V., Tebenkova, D.N., Kasakova, A.I., Kryshen, A.M., Gornov, A.V., Smirnov, V.E., Shashkov, M.P., Ershov, V.V., 

Knyazeva, S.V., 2019. The influence of vegetation on the forest soil properties in the Republic of Karelia. Eurasian Soil Science, 52: 793-807.

Merilä P., Mustajärvi, K., Helmisaari, H-S., Hilli, S., Lindroos, A-J., Nieminen, T.M., Nöjd, P., Rautio, P., Salemaa, M., Ukonmaanaho, L., 2014. Above-and below-ground N stocks in coniferous boreal forests in Finland: Implications for sustainability of more intensive biomass utilization. Forest Ecology and Management 311: 17-28. https://doi.org/10.1016/j.foreco.2013.06.029

Meyer M., Schröder W., Nickel S., Leblond S., Lindroos A.-J., Mohr K., Poikolainen J., Santamaria J.M., Skudnik M., Thöni L., Beudert B., Dieffenbach-Fries H., SchulteBisping H., Zechmeister H.G. 2015. Relevance of canopy drip for accumulation of nitrogen in moss used as biomonitors for atmospheric nitrogen deposition in Europe. Science of the Total Environment 538, 600-610. https://doi.org/10.1016/j.scitotenv.2015.07.069

Mustajärvi K., Merilä P., Derome J., Lindroos A.-J., Helmisaari H.-S., Nöjd P., Ukonmaanaho L., 2008. Fluxes of dissolved organic and inorganic nitrogen in relation to stand characteristics and latitude in Scots pine and Norway spruce stands in Finland. Boreal Environment Research 13 (suppl. B), 3-21.

Neff J.C., Holland E.A., Dentener F.J., McDowell W.H., Russell K.M., 2002. The origin, composition and rates of organic nitrogen deposition: A missing piece of the nitrogen cycle? Biogeochemistry 57, 99-136. https://doi.org/10.1023/A:101579162

Neirynck J. Kowalski A.S., Carrara A., Genouw G., Berghmans P., Ceulemans R. 2007. Fluxes of oxidized and reduced nitrogen above a mixed coniferous forest exposed to various nitrogen emission sources. Environmental Pollution 149, 3143. https://doi.org/10.1016/j.envpol.2006.12.029 
691 Nordin, A., Strengbom, J., Ericson, L., 2006. Responses to ammonium and nitrate additions

692

693

694

695

696

697

698

699

700

701

702

703

704

705

706

707

708

709

710

711

712

713 by boreal plants and their natural enemies. Environmental Pollution 141, 167-174. https://doi.org/10.1016/j.envpol.2005.08.017

Perring M.P. Diekmann, M., Midolo G. et al. 2018. Understanding context dependency in the response of forest understorey plant communities to nitrogen deposition. Environmental Pollution 242, 1787-1799.

Pitcairn, C.E.R., Leith, I.D., Sheppard, L.J., Sutton, M.A., Fowler, D., Munro, R.C.Tang, S., Wilson, D., 1998. The relationship between nitrogen deposition, species composition and foliar nitrogen concentrations in woodland flora in the vicinity of livestock farms. Environmental Pollution 102 (S1), 41-48. https://doi.org/10.1016/S02697491(98)80013-4

Pitcairn C., Fowler D., Leith I., Sheppard L., Tang S., Sutton M., Famulari D., 2006. Diagnostic indicators of elevated nitrogen deposition. Environmental Pollution 144, 941-950. https://doi.org/10.1016/j.envpol.2006.01.049

Poikolainen J., Piispanen J., Karhu J., Kubin E., 2009. Long-term changes in nitrogen deposition in Finland (1990-2006) monitored using the moss Hylocomium splendens. Environmental Pollution 157, 3091-3097. https://doi.org/10.1016/j.envpol.2009.05.018

R Core Team, 2017. R: A language and environment for statistical computing. R Foundation for Statistical Computing, Vienna, Austria. URL https://www.R-project.org/

Rousk, K., Jones, D.L., DeLuca, T.H., 2013. Moss-cyanobacteria associations as biogenic sources of nitrogen in boreal forest ecosystems. Frontiers in microbiology 4, 150, https://doi.org/10.3389\%2Ffmicb.2013.00150 
Salemaa M., Mäkipää R., Oksanen J., 2008. Differences in the growth response of three bryophyte species to nitrogen. Environmental Pollution 152, 82-91. https://doi.org/10.1016/j.envpol.2007.05.019

Salemaa, M., Lindroos, A.-J., Merilä, P., Mäkipää, R. \& Smolander, A., 2019. N2 fixation associated with the bryophyte layer is suppressed by low levels of nitrogen deposition in boreal forests. Science of the Total Environment 653: 995-1004. https://doi.org/10.1016/j.scitotenv.2018.10.364

SFS-EN ISO 11732, 2001. Water quality. Determination of ammonium nitrogen. Method by Flow Analysis (CFA and FIA) and Spectrometric Detection (ISO 11732:2005).

SFS-EN ISO 13395, 2001. Water quality. Determination of Nitrite Nitrogen and Nitrate Nitrogen and the Sum of Both by Flow Analysis (CFA and FIA) and Spectrometric Detection (ISO 13395:1996).

Skudnik M., Jeran Z., Batic F., Simoncic P., Lojen S., Kastelec D., 2014. Influence of canopy drip on the indicative $\mathrm{N}, \mathrm{S}$ and $\delta 15 \mathrm{~N}$ content in moss Hypnum cupressiforme. Environmental Pollution 190, 27-35. https://doi.org/10.1016/j.envpol.2014.03.016

Solga A., Frahm J.-P. 2006. Nitrogen accumulation by six pleurocarpous moss species and their suitability for monitoring nitrogen deposition. Journal of Bryology 28, 46-52. https://doi.org/10.1179/174328206X104552

Song L., Lu H-Z., Xu X-L., Li S., \& Liu, W.-Y., 2016. Organic nitrogen uptake is a significant contributor to nitrogen economy of subtropical epiphytic bryophytes. Nature/ Scientific Reports 6:30408. https://doi.org/10.1038/srep30408

STATISTIX 10.0. Analytical Sofware, 2013. https://www.statistix.com/ Tamminen, P. 2000. Soil factors. In: Mälkönen E. (ed.), Forest condition in a changing environment - The Finnish case, pp. 72-86. Kluwer Academic Publishers. 
738 Ukonmaanaho, L. \& Starr, M., 2001. The importance of leaching from litter collected in litterfall traps. Environental Monitoring and Assessment 66, 129 -146. https://doi.org/10.1023/A:1026432315707

741 Ukonmaanaho, L., Merilä, P., Nöjd, P., Nieminen, T.M., 2008. Litterfall production and nutrient return to the forest floor in Scots pine and Norway spruce stands in Finland. Boreal Environment Research 13 (suppl. B), 67-91.

744

van den Elzen, E., van den Berg, L.J., van der Weijden, B., Fritz, C., Sheppard, L.J., Lamers, L.P.M., 2018. Effects of airborne ammonium and nitrate pollution strongly differ in peat bogs, but symbiotic nitrogen fixation remains unaffected. Science of the Total Environment 610, 732-740, https://doi.org/10.1016/j.scitotenv.2017.08.102

748 Wiedermann M.M., Gunnarsson U., Ericsson L., Nordin A. 2009. Ecophysiological 749 adjustment of two Sphagnum species in response to anthropogenic $\mathrm{N}$ deposition. New Phytologist 181, 208-217. https://doi.org/10.1111/j.1469-8137.2008.02628.x 


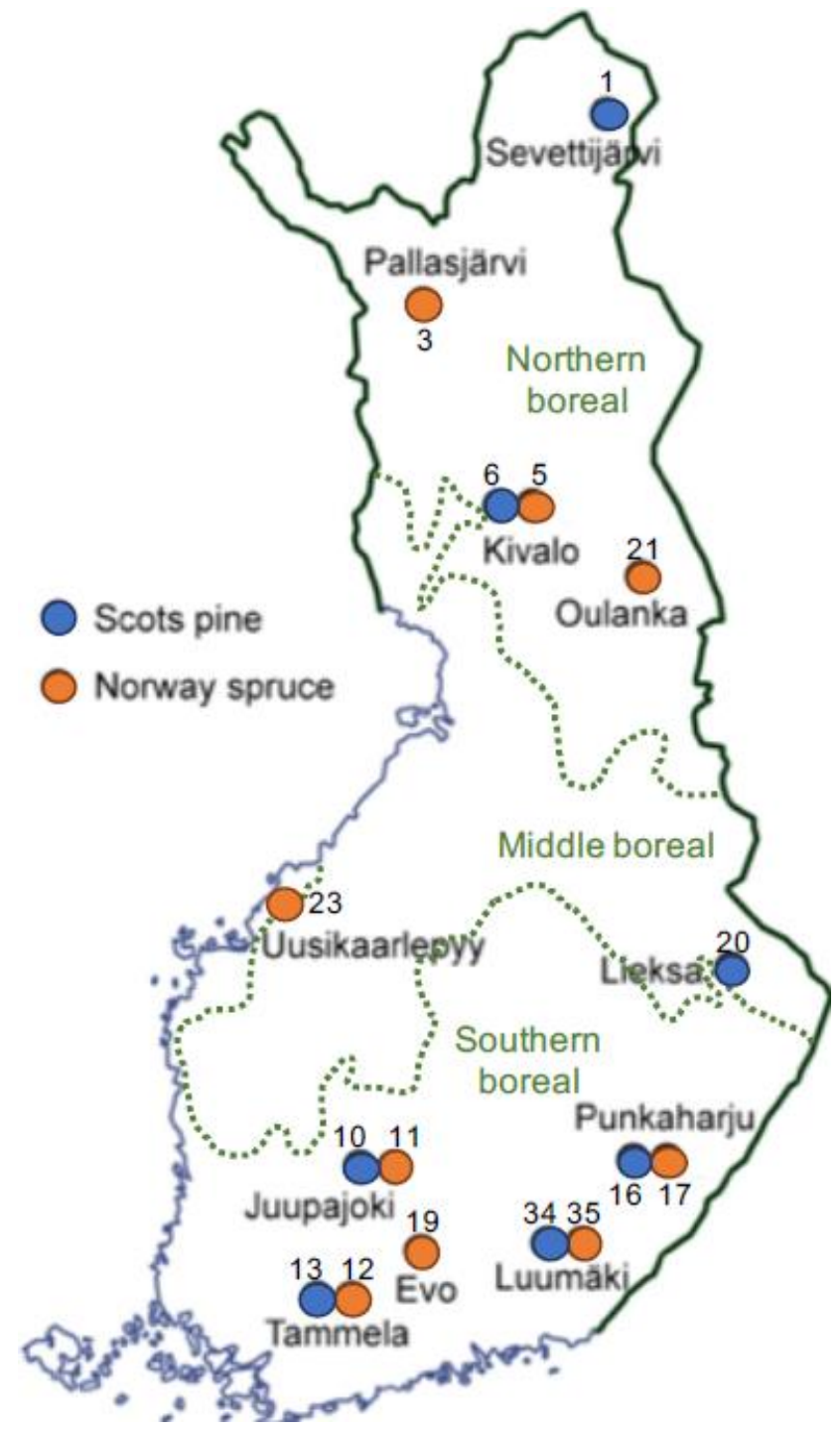

Figure 1. Location of the plots and distribution of the vegetation zones in Finland. ICP Forests plot code shown. In the data analysis "south" = southern boreal and "north" = middle and northern boreal subzones. 


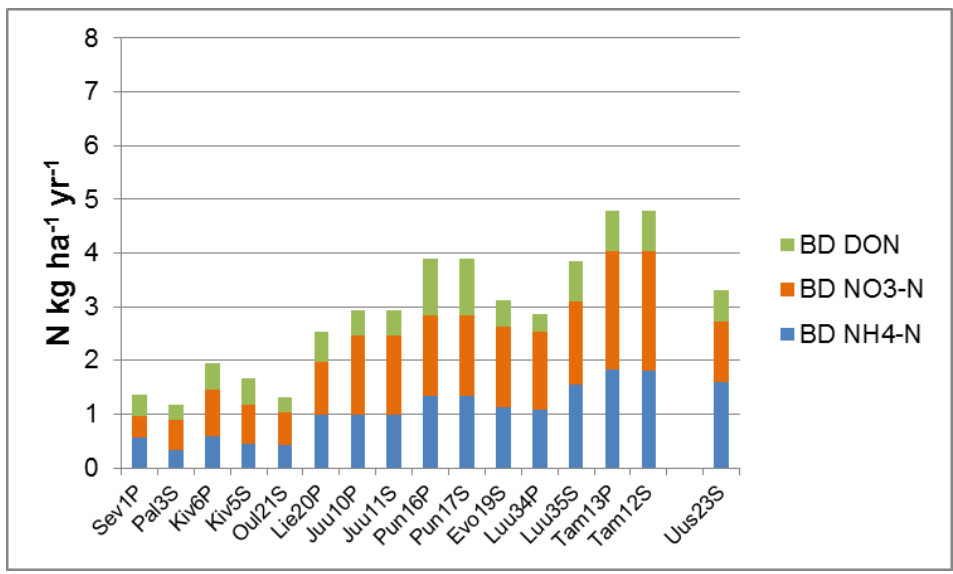

761

b)

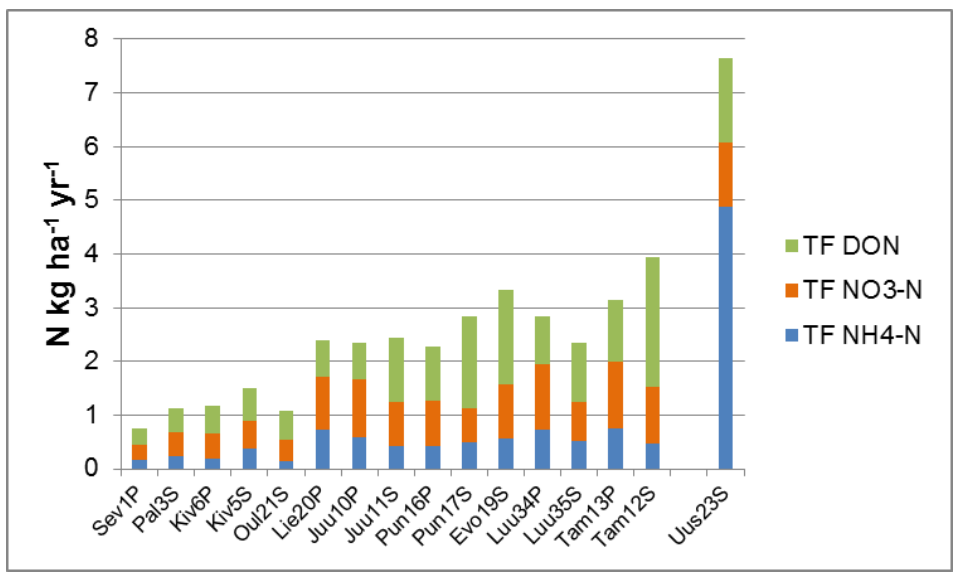

763 c)

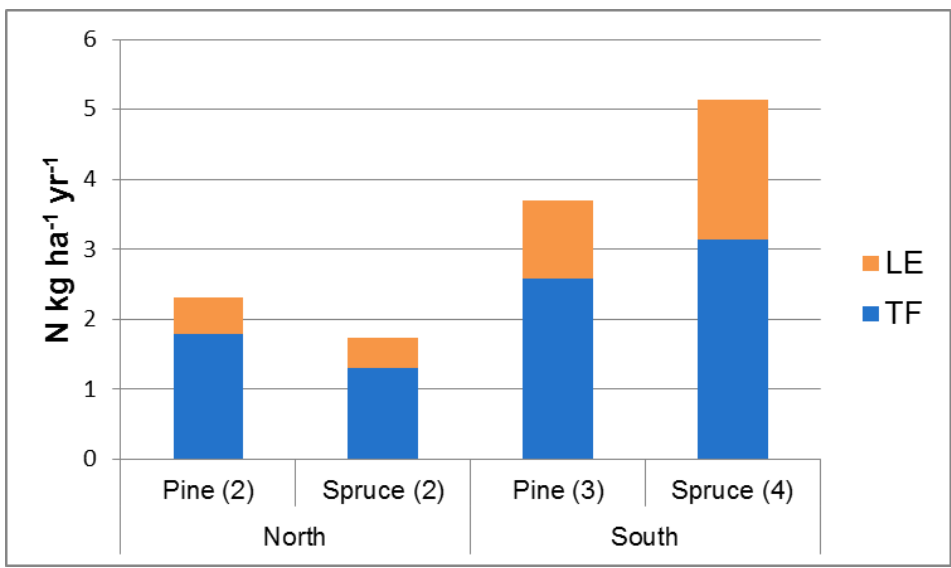

Figure 2. Amount of different $\mathrm{N}$ forms in a) bulk (BD) and b) throughfall (TF) deposition (averages across 2007-2009, see Suppl. Table S.2). Plots ordered according to $\mathrm{N}$ latitude (Table 2) from north to south (left - right). $P=$ Scots pine and $S=$ Norway spruce in the plot names. Plot Uus $23 S$ is an outlier and positioned far right. c) Average amount of $\mathrm{N}_{\text {tot }}$ in TF and in leachate (LE) from litterfall (shed needles and other canopy material) in the southern and northern pine and spruce plots (number of plots in parenthesis). The amount of $\mathrm{N}$ in LE was calculated as $6 \%$ from the $\mathrm{N}$ of litterfall

771 (Ukonmaanaho and Starr 2001). 

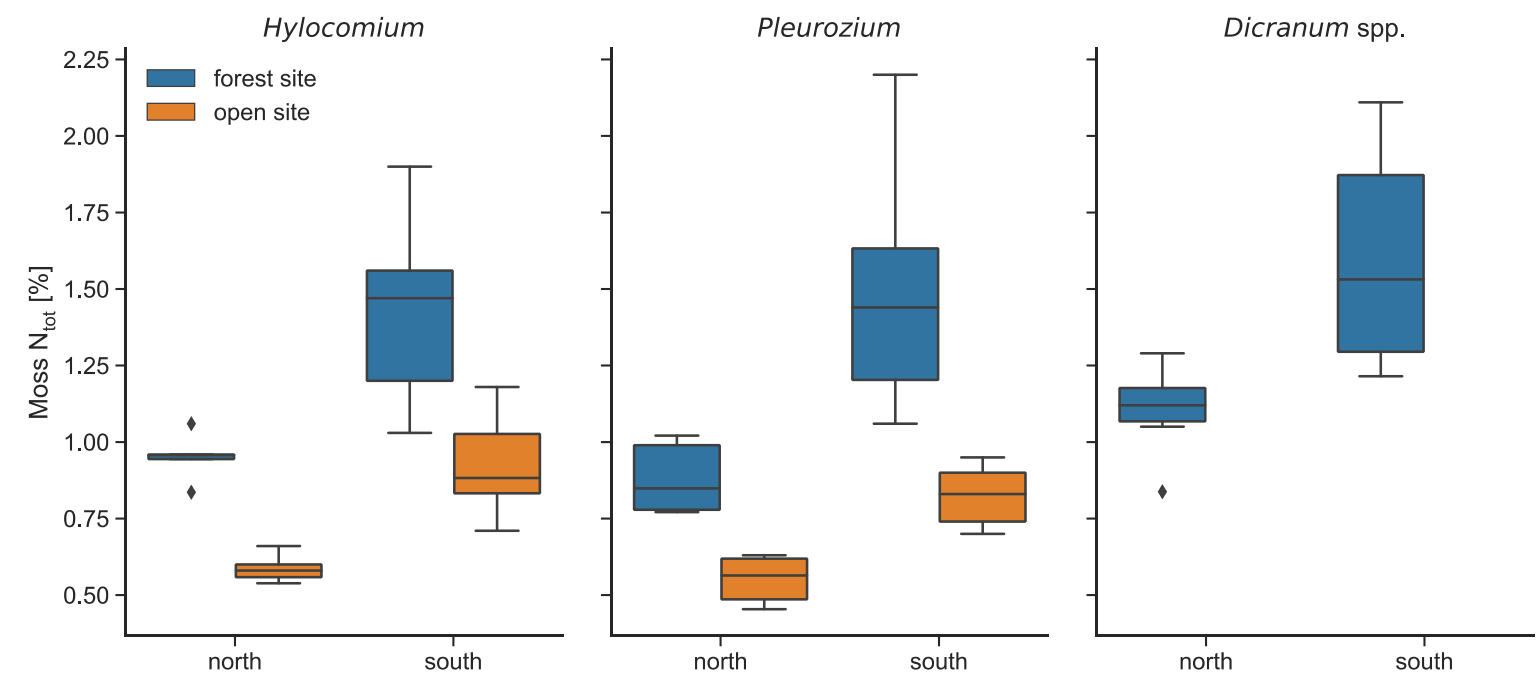

773

774

b)
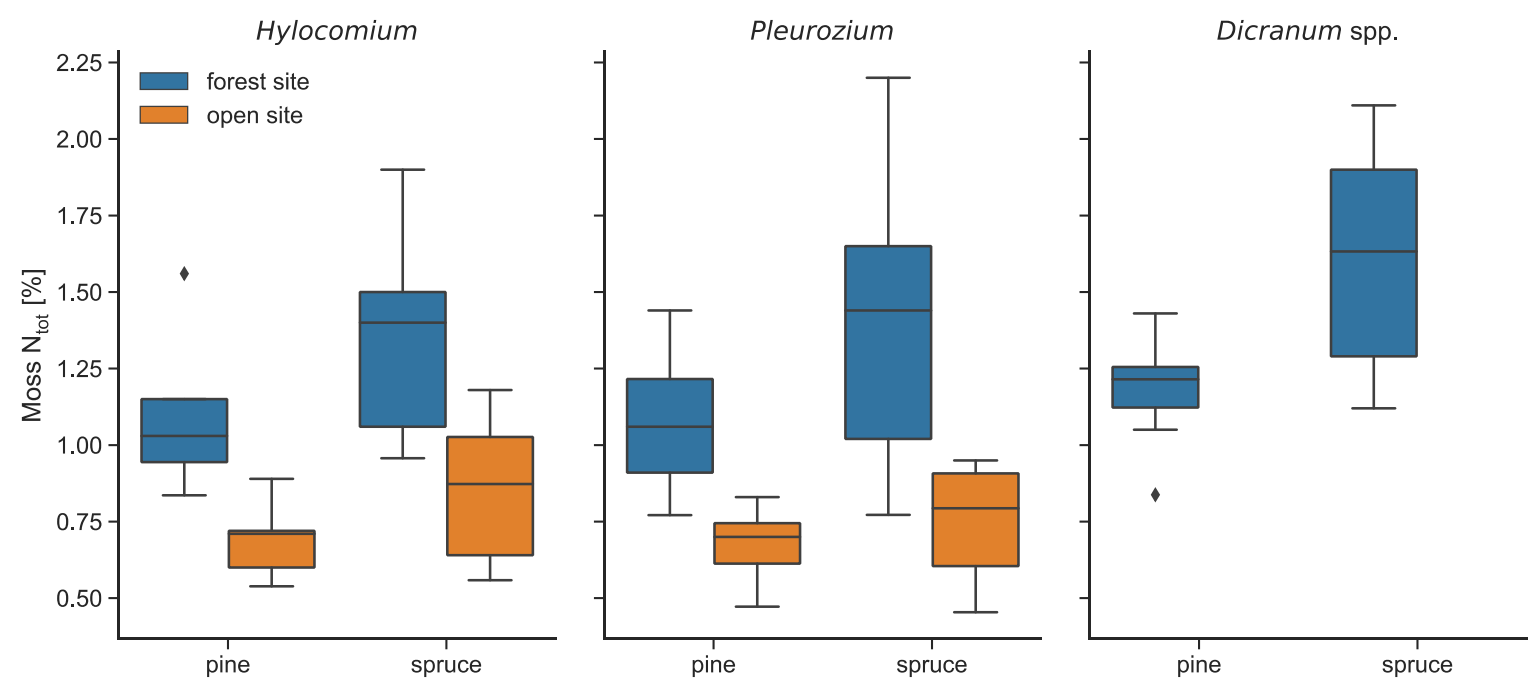

775

776 Figure 3. Box-plot diagrams of total mossN\% of three species (Pleurozium schreberi,

777 Hylocomium splendens and Dicranum spp.) collected from forests and open sites a) in

778 northern vs. southern parts of Finland and b) in Scots pine vs. Norway spruce dominated

779 areas. Middle line in a box is a median, the box shows $75 \%$ and $25 \%$ percentiles, and the

780 whiskers denote $97.5 \%$ and $3.5 \%$ percentiles. 

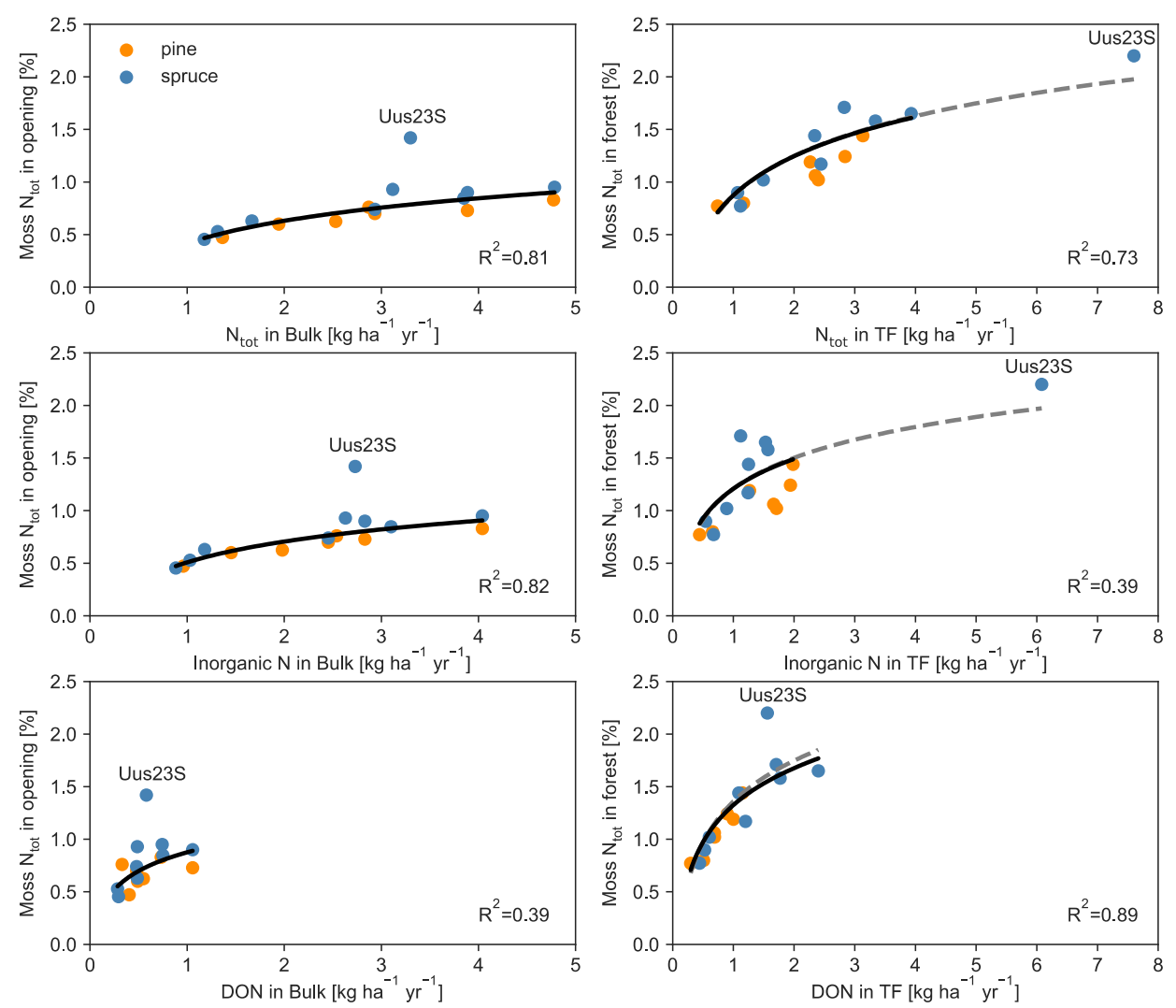

783

b) Hylocomium splendens
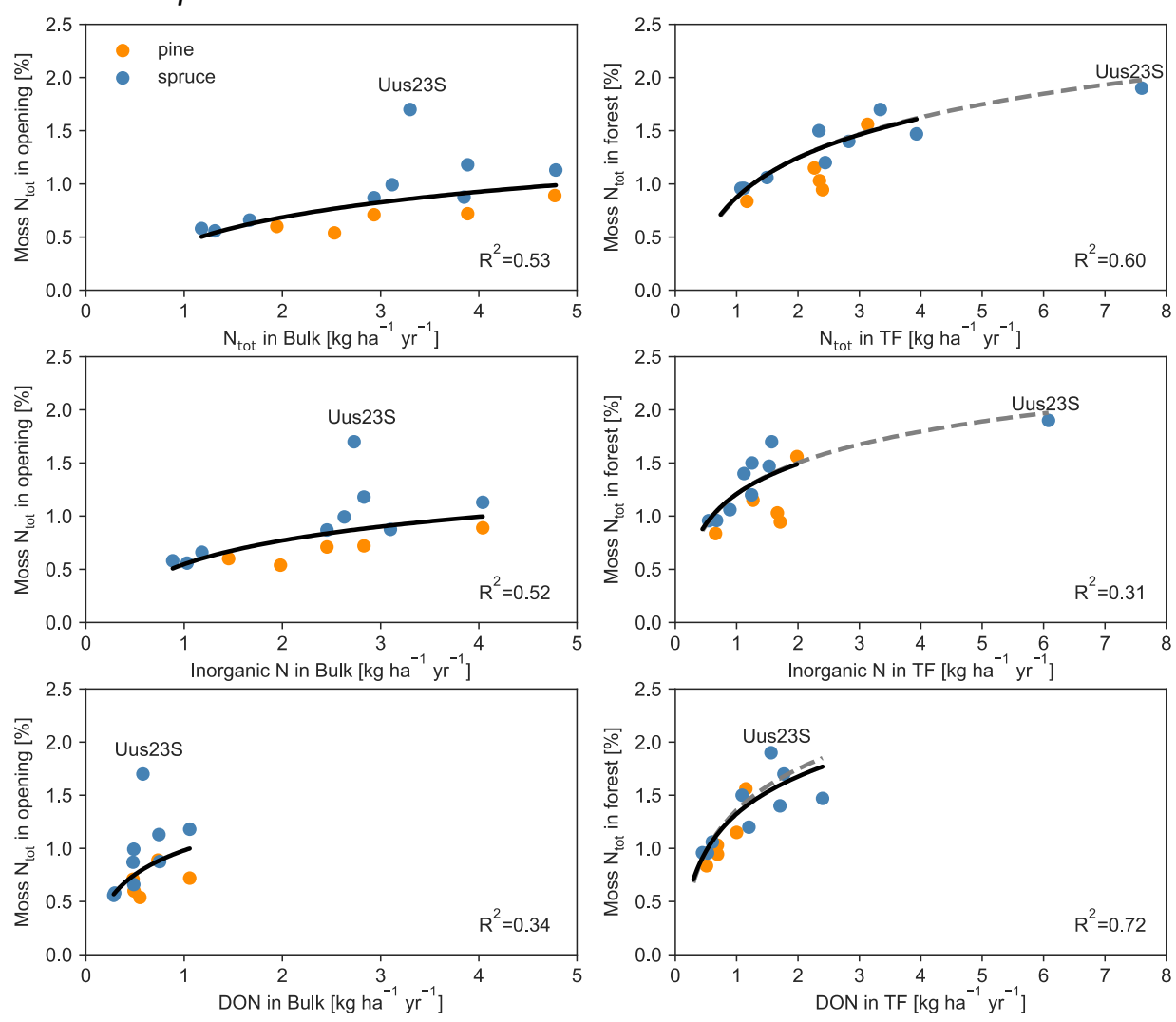

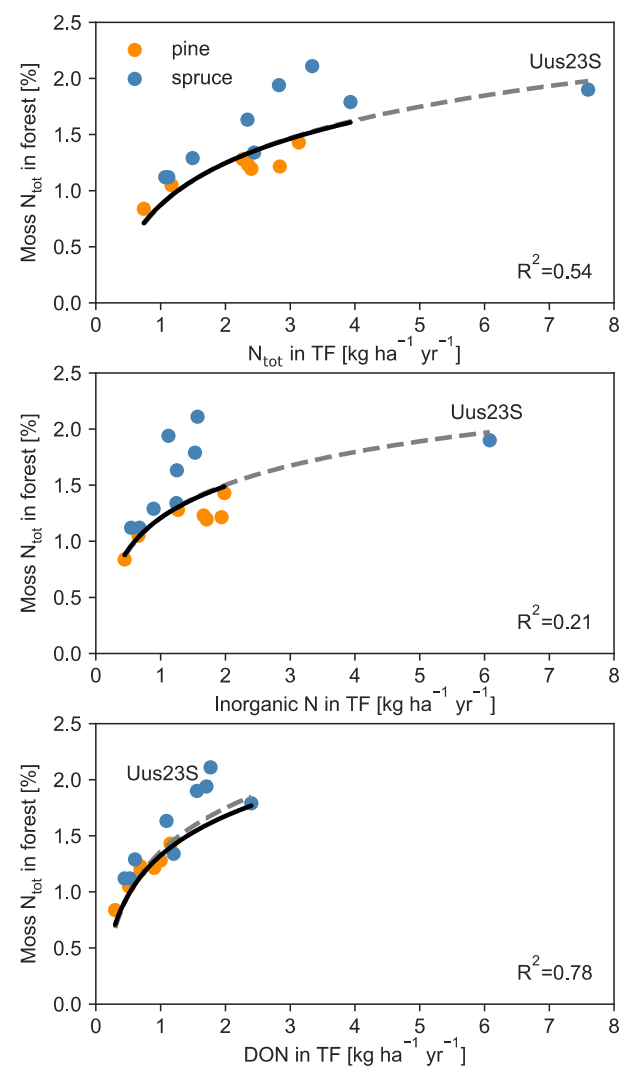

789 Figure 4. Total moss $N \%$ in relation to different $\mathrm{N}$ forms ( $\mathrm{N}_{\text {tot, }} \mathrm{N}_{\text {inorg }}$ and DON) in bulk 790 (samples from openings) and in throughfall (TF) deposition (samples from forests) for a) 791 Pleurozium schreberi, b) Hylocomium splendens and c) Dicranum spp. (only forest samples). 792 Dominant tree species in the sampling site given in the point colour. The outlier plot Uus23S 793 (near a fox farm), marked as a point in figures, is excluded in the basic models (solid line), 794 but included in the extended TF models (dashed line). $R^{2}$ value tells the fit of the basic 795 model. Model tables for response curves in Supplement Table S.4a,b. 

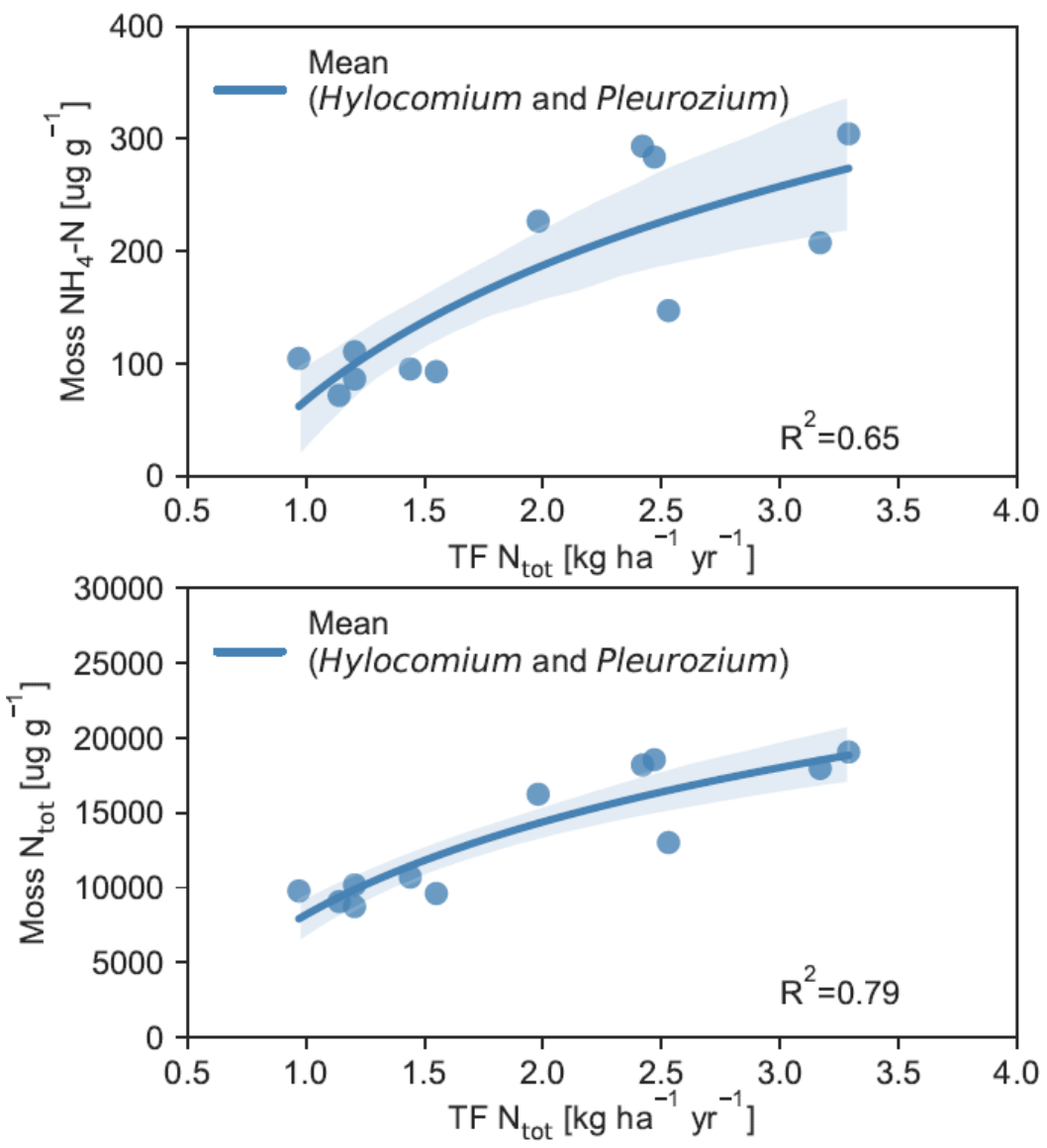

798 Figure 5. Accumulation curves with $95 \%$ confidence intervals for a) $\mathrm{NH}_{4}{ }^{+}-\mathrm{N}$ and b) $\mathrm{N}_{\text {tot }}$ ( $\mu \mathrm{g} \mathrm{g}$ $799{ }^{1}$ ) in moss tissues (mean of $P$. schreberi and $H$. splendes, years 2002 or 2003) vs. TF $N_{\text {tot }}$ 800 deposition. 

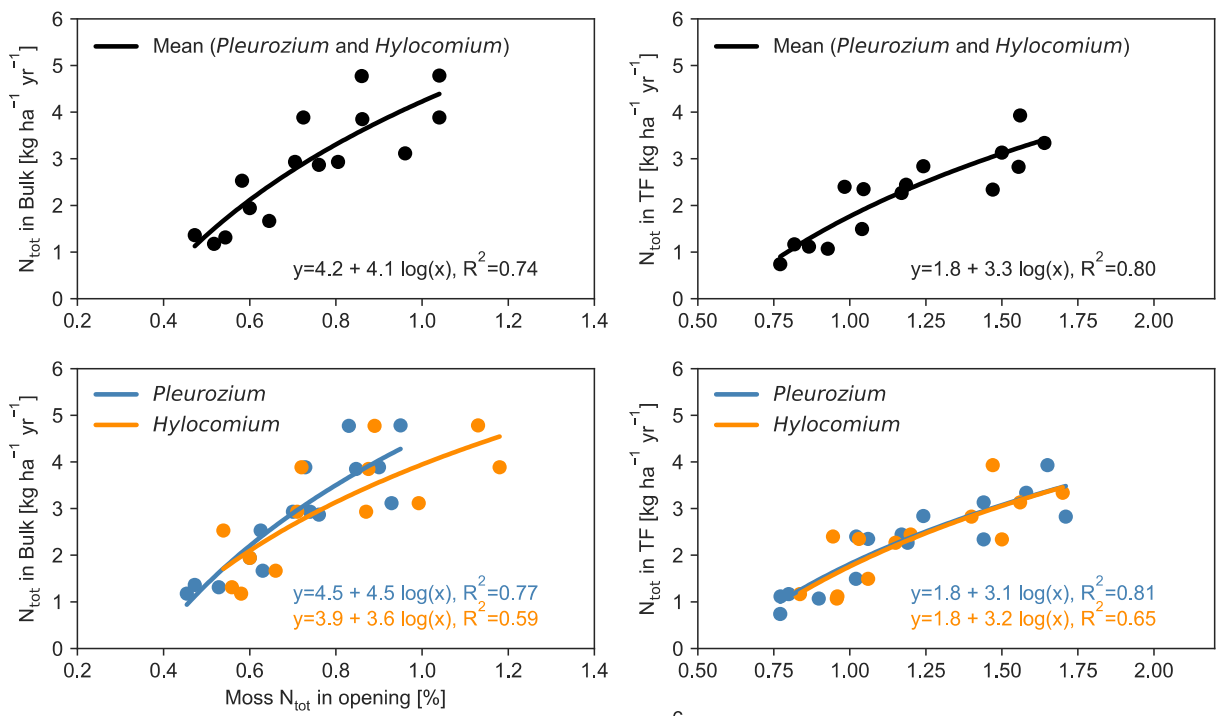

803

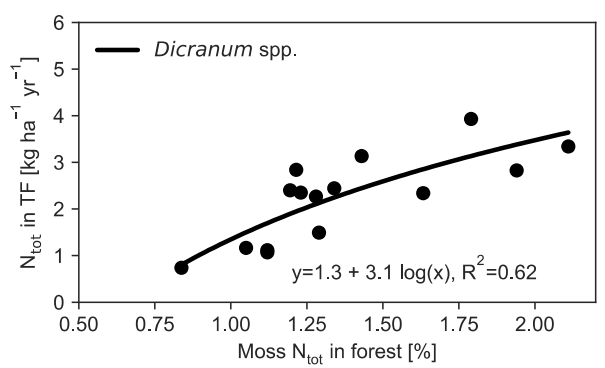

804 Figure 6. Response curves for the total $\mathrm{N}$ deposition (y) in the background forests of Finland 805 using mossN\% as a predictor (x). Left side column: bulk $\mathrm{N}_{\text {tot }}$ deposition vs. moss samples

806 from forest openings and right side column: TF $N_{\text {tot }}$ deposition vs. moss samples inside 807 forest. Mean mossN\% values of the two feather mosses is used as a preditor in models in 808 the upper row and separate models are given for $P$. schreberi and $H$. splendens in the 809 middle. 
813

\begin{tabular}{|c|c|c|c|c|c|}
\hline $\begin{array}{l}\text { Sub- } \\
\text { sample }\end{array}$ & Habitat & $\begin{array}{l}\text { Sample } \\
\text { years of } \\
\text { mosses }\end{array}$ & $\begin{array}{l}\mathrm{N} \text { forms in } \\
\text { mosses }\end{array}$ & $\begin{array}{l}\text { Sample years of } \\
\text { deposition, prec. }\end{array}$ & $\begin{array}{l}\mathrm{N} \text { forms in } \\
\text { deposition }\end{array}$ \\
\hline 1 & $\begin{array}{l}\text { Forest } \\
n=16\end{array}$ & 2009 & $\mathrm{~N}_{\text {tot }}$ & TF: 2007 - 2009 & $\begin{array}{l}\mathrm{N}_{\text {tot }}, \mathrm{NH}_{4}{ }^{+}-\mathrm{N}, \\
\mathrm{NO}_{3}-\mathrm{N}, \mathrm{DON}\end{array}$ \\
\hline 2 & $\begin{array}{l}\text { Opening } \\
\mathrm{n}=11\end{array}$ & $2009(2010)$ & $\mathrm{N}_{\text {tot }}$ & BD: $2007-2009$ & $\begin{array}{l}\mathrm{N}_{\text {tot }}, \mathrm{NH}_{4}{ }^{+}-\mathrm{N}, \\
\mathrm{NO}_{3}-\mathrm{N}, \mathrm{DON}\end{array}$ \\
\hline 3 & $\begin{array}{l}\text { Forest } \\
n=10\end{array}$ & $2002(2003)$ & $\begin{array}{l}\mathrm{N}_{\text {tot }}, \mathrm{NH}_{4}^{+}-\mathrm{N}, \\
\mathrm{NO}_{3}{ }^{-}-\mathrm{N}, \mathrm{DON}\end{array}$ & $\begin{array}{l}\text { TF: } 2000-2002 \\
(2001-2003)\end{array}$ & $\begin{array}{l}\mathrm{N}_{\text {tot }}, \mathrm{NH}_{4}{ }^{+}-\mathrm{N}, \\
\mathrm{NO}_{3}-\mathrm{N}, \mathrm{DON}\end{array}$ \\
\hline
\end{tabular}

814

815 Table 1. Overview of measurements in the three subsamples of mosses, $\mathrm{N}$ deposition and 816 precipitation (prec.) in different years. $n=$ total number of sites. Years in parenthesis include 8172 - 3 sites. TF = throughfall, $\mathrm{BD}=$ bulk deposition. We calculated three-year averages of the 818 deposition values corresponding the growth period of moss shoots used in chemical 819 analyses. 


\begin{tabular}{|c|c|c|c|c|c|c|c|c|c|c|c|c|}
\hline \multirow[b]{2}{*}{$\begin{array}{l}\text { ICP Forests } \\
\text { plot name }\end{array}$} & \multirow[b]{2}{*}{ Plot abbr. } & \multirow[b]{2}{*}{$\mathrm{N}$ latitude } & \multicolumn{5}{|l|}{ Forest } & \multicolumn{3}{|l|}{ Forest } & \multicolumn{2}{|l|}{ Opening } \\
\hline & & & $\begin{array}{l}\text { Tree } \\
\text { species }\end{array}$ & $\begin{array}{l}\text { Basal area } \\
\mathrm{m}^{2} \mathrm{ha}^{-1}\end{array}$ & $\begin{array}{l}\text { Canopy } \\
\text { cover\% }\end{array}$ & $\begin{array}{c}\text { Org. soil } \\
\text { C:N }\end{array}$ & $\begin{array}{l}\text { Mosses } \\
\text { cover \% }\end{array}$ & $\begin{array}{l}\text { Hylo sple } \\
\text { mossN\% }\end{array}$ & $\begin{array}{l}\text { Pleu schr } \\
\text { mossN\% }\end{array}$ & $\begin{array}{l}\text { Dicr spp. } \\
\text { mossN\% }\end{array}$ & $\begin{array}{l}\text { Hylo sple } \\
\text { mossN\% }\end{array}$ & $\begin{array}{l}\text { Pleu schr } \\
\text { mossN\% }\end{array}$ \\
\hline Sevettijärvi1P & Sev1P & $69^{\circ} 34^{\prime}$ & pine & 13.5 & 35 & 50.2 & 17 & & 0.8 & 0.8 & & $0.5^{\mathrm{m}}$ \\
\hline Pallasjärvi3S & Pal3S & $67^{\circ} 59^{\prime}$ & spruce & 15.4 & 40 & 46.3 & 93 & 1.0 & 0.8 & 1.1 & 0.6 & $0.5^{\mathrm{m}}$ \\
\hline Kivalo6P & Kiv6P & $66^{\circ} 21^{\prime}$ & pine & 18.9 & 23 & 46.8 & 89 & 0.8 & 0.8 & 1.1 & 0.6 & 0.6 \\
\hline Kivalo5S & Kiv5S & $66^{\circ} 19^{\prime}$ & spruce & 18.0 & 33 & 41.3 & 90 & 1.1 & 1.0 & 1.3 & 0.7 & 0.6 \\
\hline Oulanka21S & Oul21S & $66^{\circ} 18^{\prime}$ & spruce & 21.0 & 48 & 53.4 & 90 & 1.0 & 0.9 & 1.1 & $0.6^{m}$ & $0.5^{\mathrm{m}}$ \\
\hline Lieksa20P & Lie20P & $63^{\circ} 09^{\prime}$ & pine & 22.3 & 28 & 52.6 & 93 & 0.9 & 1.0 & 1.2 & $0.5^{\mathrm{m}}$ & $0.6^{\mathrm{m}}$ \\
\hline Uusikaarlepyy23S* & Uus23S & $63^{\circ} 33^{\prime}$ & spruce & 32.7 & 51 & 21.7 & 40 & 1.9 & 2.2 & 1.9 & 1.7 & 1.4 \\
\hline Juupajoki10P & Juu10P & $61^{\circ} 52^{\prime}$ & pine & 23.6 & 29 & 35.4 & 90 & 1 & 1.1 & 1.2 & 0.7 & 0.7 \\
\hline Juupajoki11S & Juu11s & $61^{\circ} 51^{\prime}$ & spruce & 30.4 & 35 & 34.9 & 57 & 1.2 & 1.2 & 1.3 & 0.9 & 0.7 \\
\hline Punkaharju16P & Pun16P & $61^{\circ} 46^{\prime}$ & pine & 32.0 & 60 & 35.1 & 96 & 1.2 & 1.2 & 1.3 & 0.7 & $0.7^{m}$ \\
\hline Punkaharju17S & Pun17S & $61^{\circ} 48^{\prime}$ & spruce & 30.8 & 42 & 31.7 & 75 & 1.4 & 1.7 & 1.9 & 1.2 & 0.9 \\
\hline Evo19s & Evo19s & $61^{\circ} 14^{\prime}$ & spruce & 49.7 & 73 & 30.8 & 43 & 1.7 & 1.6 & 2.1 & $1^{m}$ & $0.9^{m}$ \\
\hline Luumäki34P & Luu34P & $60^{\circ} 55^{\prime}$ & pine & 13.6 & 33 & 40.0 & 38 & & 1.2 & 1.2 & & $0.8^{m}$ \\
\hline Luumäki35S & Luu35S & $60^{\circ} 55^{\prime}$ & spruce & 28.2 & 65 & 26.7 & 84 & 1.5 & 1.4 & 1.6 & $0.9^{m}$ & $0.8^{m}$ \\
\hline Tammela13P & Tam13P & $60^{\circ} 36^{\prime}$ & pine & 29.3 & 34 & 34.0 & 60 & 1.6 & 1.4 & 1.4 & $0.9^{m}$ & $0.8^{m}$ \\
\hline Tammela12S & Tam12S & $60^{\circ} 38^{\prime}$ & spruce & 33.1 & 69 & 30.5 & 72 & 1.5 & 1.7 & 1.8 & 1.1 & 1.0 \\
\hline
\end{tabular}

Table 2. Stand characteristics of the forest plots and mossN\% of Hylocomium splendens (Hylo sple), Pleurozium schreberi (Pleu schr) and

823 Dicranum spp. (Dicr spp.) collected inside (2009) and outside (2009-2010) forests. Missing data in openings modelled (marked ${ }^{\mathrm{m}}$ ). Plots ordered 824 along the north-south gradient (N latitude). The first six plots in the list belong to "north" and the remainder ten to "south". Location of the plots marked in Fig. 1. Stand basal area and cover \% mosses from the year 2009, C:N ratio of the organic soil layer from 2006 and cover\% of tree canopy from 2014. Pine $=$ Pinus sylvestris, spruce $=$ Picea abies. $*$ : Uus23S is an outlier plot owing to high $\mathrm{N}$ emissions from a nearby fox farm. 


\begin{tabular}{|c|c|c|c|c|c|c|c|}
\hline \multirow[b]{3}{*}{ Mode } & \multirow[b]{3}{*}{ Predictor } & \multicolumn{3}{|c|}{ Bulk deposition } & \multicolumn{3}{|c|}{ TF deposition } \\
\hline & & \multirow[b]{2}{*}{$\mathrm{R}^{2}$} & \multicolumn{2}{|l|}{$P$ values } & \multirow[b]{2}{*}{$R^{2}$} & \multicolumn{2}{|l|}{$P$ values } \\
\hline & & & $\begin{array}{l}\mathrm{N} \text { form, } \\
\text { stand }\end{array}$ & $\begin{array}{l}\text { Interact } \\
\text {. }\end{array}$ & & $\begin{array}{l}\mathrm{N} \text { form, } \\
\text { stand }\end{array}$ & Interact. \\
\hline \multicolumn{8}{|c|}{ a) Pleurozium schreberi } \\
\hline 1 & $\mathrm{~N}_{\text {tot }}$ & 80.8 & 0.001 & & 73.4 & 0.001 & \\
\hline 2 & $\mathrm{~N}_{\text {tot }}+$ Tree $+\mathrm{N}_{\text {tot }}:$ Tree & 89.8 & $\begin{array}{l}0.001 \\
\mathrm{~ns}^{\top}\end{array}$ & ns & 82.7 & $0.001, \mathrm{~ns}^{\top}$ & 0.08 \\
\hline 3 & $\mathrm{NH}_{4}-\mathrm{N}$ & 74.4 & 0.001 & & 39.6 & 0.007 & \\
\hline 4 & $\mathrm{NO}_{3}-\mathrm{N}$ & 80.0 & 0.001 & & 35.6 & 0.011 & \\
\hline 5 & DON & 39.2 & 0.007 & & 89.1 & 0.001 & \\
\hline 6 & $N_{\text {inorg }}$ & 81.5 & 0.001 & & 39.3 & 0.007 & \\
\hline 7 & $\mathrm{~N}_{\text {inorg}}+\mathrm{DON}$ & 80.0 & $\begin{array}{l}0.001^{i}, \mathrm{~ns} \\
\mathrm{D}\end{array}$ & & 88.2 & $n s^{i}, 0.01^{D}$ & \\
\hline 8 & $\mathrm{~N}_{\text {inorg }}+\mathrm{DON}: \mathrm{BA}$ & 81.9 & 0.001 & ns & 84.9 & 0.106 & 0.001 \\
\hline \multicolumn{8}{|c|}{ b) Hylocomium splendens } \\
\hline 1 & $\mathrm{~N}_{\text {tot }}$ & 52.5 & 0.003 & & 59.7 & 0.001 & \\
\hline 2 & $\mathrm{~N}_{\text {tot }}+$ Tree $+\mathrm{N}_{\text {tot }}:$ Tree & 83.1 & $0.03, \mathrm{~ns}^{\top}$ & ns & 66.8 & $0.03, \mathrm{~ns}^{\top}$ & ns \\
\hline 3 & $\mathrm{NH}_{4}-\mathrm{N}$ & 46.9 & 0.006 & & 29.3 & 0.03 & \\
\hline 4 & $\mathrm{NO}_{3}-\mathrm{N}$ & 55.0 & 0.002 & & 27.3 & 0.04 & \\
\hline 5 & DON & 33.4 & 0.02 & & 71.2 & 0.001 & \\
\hline 6 & $\mathrm{~N}_{\text {inorg }}$ & 51.8 & 0.01 & & 30.2 & 0.03 & \\
\hline 7 & $\mathrm{~N}_{\text {inorg }}+\mathrm{DON}$ & 47.4 & $0.08^{\mathrm{i}}, \mathrm{ns}^{\mathrm{D}}$ & & 69.1 & $n s^{i}, 0.003^{D}$ & \\
\hline 8 & $\mathrm{~N}_{\text {inorg }}+\mathrm{DON}: \mathrm{BA}$ & 47.4 & 0.01 & ns & 71.6 & $n s^{i}$ & 0.002 \\
\hline \multicolumn{8}{|c|}{ c) Dicranum spp. } \\
\hline 1 & $\mathrm{~N}_{\text {tot }}$ & & & & 53.9 & 0.001 & \\
\hline 2 & $\mathrm{~N}_{\text {tot }}+$ Tree $+\mathrm{N}_{\text {tot }}:$ Tree & & & & 81.3 & $0.02, \mathrm{~ns}^{\top}$ & 0.06 \\
\hline 3 & $\mathrm{NH}_{4}-\mathrm{N}$ & & & & 21.5 & 0.05 & \\
\hline 4 & $\mathrm{NO}_{3}-\mathrm{N}$ & & & & 18.1 & 0.06 & \\
\hline 5 & DON & & & & 78.5 & 0.001 & \\
\hline 6 & $\mathrm{~N}_{\text {inorg }}$ & & & & 20.8 & 0.05 & \\
\hline 7 & Ninorg+DON & & & & 79.5 & $n s^{i}, 0.001 D$ & \\
\hline 8 & $\mathrm{~N}_{\text {inorg }}+\mathrm{DON}: \mathrm{BA}$ & & & & 83.4 & $n s^{i}$ & 0.001 \\
\hline
\end{tabular}

830 Table 3. Comparison of the models (no 1-8) explaining tissue N\% of three moss species 831 using different $\mathrm{N}$ forms and stand variables as predictors. Moss samples collected from open 832 sites were modelled vs. bulk (BD) and those from forests vs. throughfall (TF) deposition. For 833 Dicranum spp. only forest data was available. Adjusted $\mathrm{R}^{2}$ for models and $\mathrm{P}$ values for 834 predictors are given (the $1^{\text {st }} \mathrm{P}$ value is always for the $1^{\text {st }}$ predictor in a model). Abbreviations: 835 interact. $=$ interaction term, $\mathrm{BA}=$ stand basal area, $\mathrm{i}=\mathrm{N}_{\text {inorg }}, \mathrm{D}=\mathrm{DON}, \mathrm{T}=$ Tree species 836 (pine, spruce), ns = not significant. The outlier plot Uus23S omitted from the models. The 837 model tables are given in Supplement Table S.4a. 